Pippa Gibson

\section{Department for Environment, Food} and Rural Affairs

Sebnem Oguz and Jonathan Knight Office for National Statistics

\title{
Regional economic indicators \\ A focus on rural and urban productivity in the English regions
}

\section{Focus on rural and urban productivity in the English regions}

This quarter, the regional economic indicators article focuses on rural and urban productivity in the English regions. The regular part of the article then gives an overview of the economic activity of UK regions in terms of their gross value added (GVA), GVA per head and labour productivity. This is followed by a presentation of headline indicators of regional welfare, other drivers of regional productivity and regional labour market statistics. The indicators cover the nine Government Office Regions of England and the devolved administrations of Northern Ireland, Scotland and Wales. These 12 areas comprise level 1 of the European Nomenclature of Units for Territorial Statistics (NUTS level 1) for the UK. The term 'region' is used to describe this level of geography for convenience in the rest of this article. $\checkmark$

nderstanding the economic

performance of rural areas is an important part of government policy.

This article focuses on latest estimates of productivity at the rural and urban level within English regions. The methodology for productivity estimates at the rural and urban level for England was developed as a result of collaboration between the Office for National Statistics and the Department of Environment, Food and Rural Affairs (Defra) and presented in the November 2008 edition of this publication (DeyChowdhury and Gibson, 2008).

The local authority (LA) rural-urban classification (Defra, 2005) is based on the rural and urban definition for England and Wales in 2004 and categorises each local and unitary authority in England on a sixpoint scale of urban to rural (Box 1). This allows data published only at district level to be analysed by rurality, and allows for the production of sub-regional productivity estimates using GVA and workforce jobs estimates. Due to concerns about the robustness of hours worked data at the district level, the productivity estimates are only available on an output per filled job basis.

Rural and urban productivity in England

Previous work (Dey-Chowdhury and Gibson, 2008) has shown that while at first glance there seemed to be a productivity gap between the most rural and the most urban authorities in England in 2005, this gap was removed when London was presented separately to the other major urban areas. The updated figures for 2006 and including 2001 show that this is still the case (Figure 1). London productivity, having peaked between 2002 and 2005, shows a slight decline relative to England in 2006. Rural-80 and significant rural authorities on the other hand are showing a slight relative increase, with average productivity in rural-80 areas largely similar to that in non-London major and large urban authorities.

There is considerable interest in these estimates at a sub-national level as they can give useful information about how productivity differs within regions and where there might be opportunity to unlock potential. However due to the erratic nature of the GVA data, it is not statistically viable to produce individual estimates for each category of the LA classification for every region for individual years, because the individual categories in some regions have too few data points on which to base robust estimates. There are several options to avoid this, however: first, by combining the data into three large regional groups rather than nine regions; second, by merging the LA classification into three more general categories (described in Box 1); and finally to use an average of three years' data to produce estimates of productivity for each category of the LA classification for all regions. 
Box 1

\section{Defining 'rural' at district level}

The Rural/Urban Definition, an official National Statistic introduced in 2004, defines the rurality of small census geographies such as census output areas and wards. Areas forming settlements with populations of over 10,000 are urban, while the remainder are defined as rural town and fringe, village or hamlet and dispersed.

This definition forms the basis of the Local Authority Rural Urban classification system for England, constructed by the Rural Evidence Research Centre at Birkbeck. The categories of the classification (shown in Map 1) and criteria for identifying them are as follows:

- Major Urban (MU) - districts with either 100,000 people or 50 percent of their population living in urban areas with a population of more than 750,000 . Since local Government reorganisation in 2009, there are 71 districts in this group with an aggregate population at Census 2001 of 16.5 million.

- Large Urban (LU) - districts with either 50,000 people or 50 percent of their population living in one of 17 urban areas with a population between 250,000 and 750,000 . There are 39 districts in this group with an aggregate population of 6.6 million.

- Other Urban (OU) - districts with less than 26 percent of their population living in rural settlements and larger market towns ${ }^{1}$. There are 58 districts in this group with an aggregate population of 7.4 million.

- Significant Rural (SR) - districts with more than 26 percent but less than 50 percent of their population living in rural settlements and larger market towns. There are 55 districts in this group with an aggregate population of 6.7 million.
- Rural-50 (R50) - districts with at least 50 percent but less than 80 percent of their population living in rural settlements and larger market towns. There are 48 districts in this group with an aggregate population of 6.9 million.

- Rural-80 (R80) - districts with at least 80 percent of their population living in rural settlements and larger market towns. There are 55 districts in this group with an aggregate population of 5 million.

\section{Higher tier classification}

Where categories of the LA classification need to be combined either to avoid disclosure or to improve the robustness of data, they are aggregated into three groups as follows:

- Predominantly Urban: combines Major, Large and Other Urban authorities.

- Significant Rural: as with the six-way classification, this category includes just those authorities with more than 26 and less than 50 percent of their population in rural settlements and large market towns.

- Predominantly Rural: combines Rural-50 and Rural-80 authorities.

These classifications form the basis of the estimates of ruralurban productivity presented here. More detailed methodological information can be found at

www. defra.gov.uk/rural/ruralstats/rural-definition.htm and notes on how to combine the categories of the classification are at

www.defra.gov.uk/rural/ruralstats/rural-defn/ rural-stats-guidance.pdf.

\section{Figure 1}

\section{GVA per job by LA classification, 2001-2006}

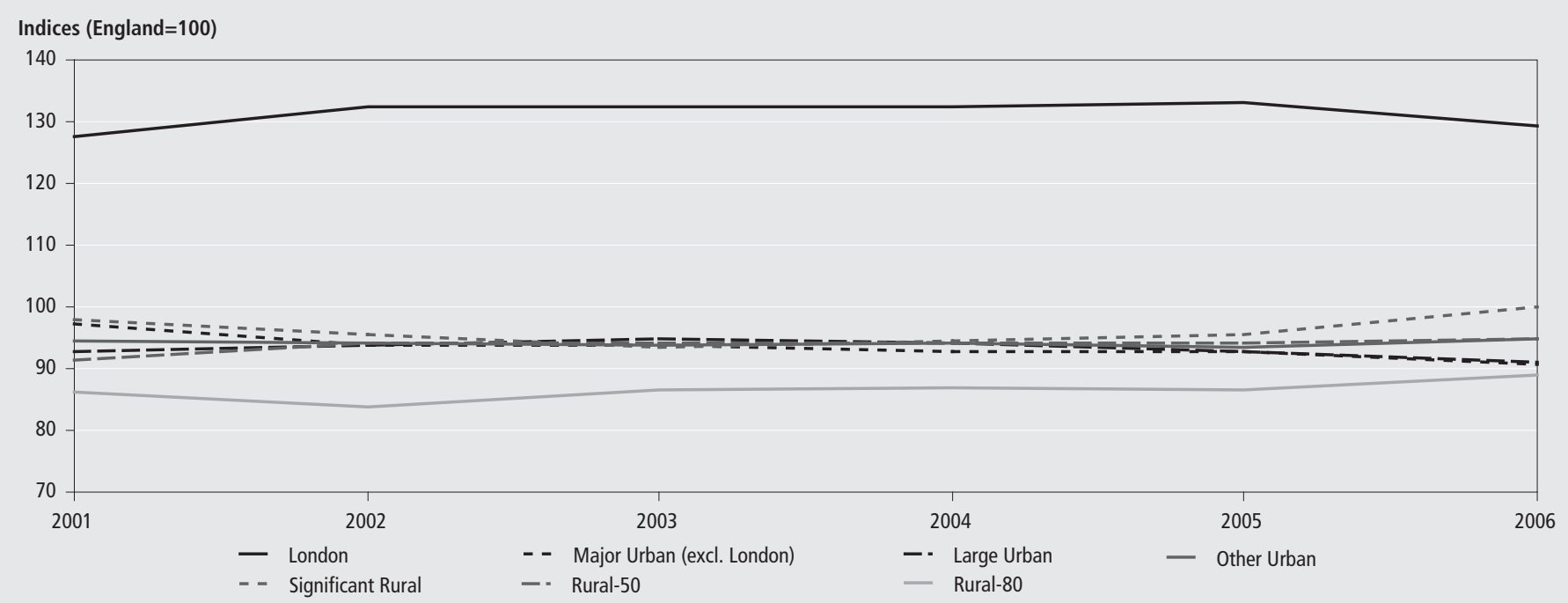




\section{Map 1}

Local Authority Rural/Urban Classification for England

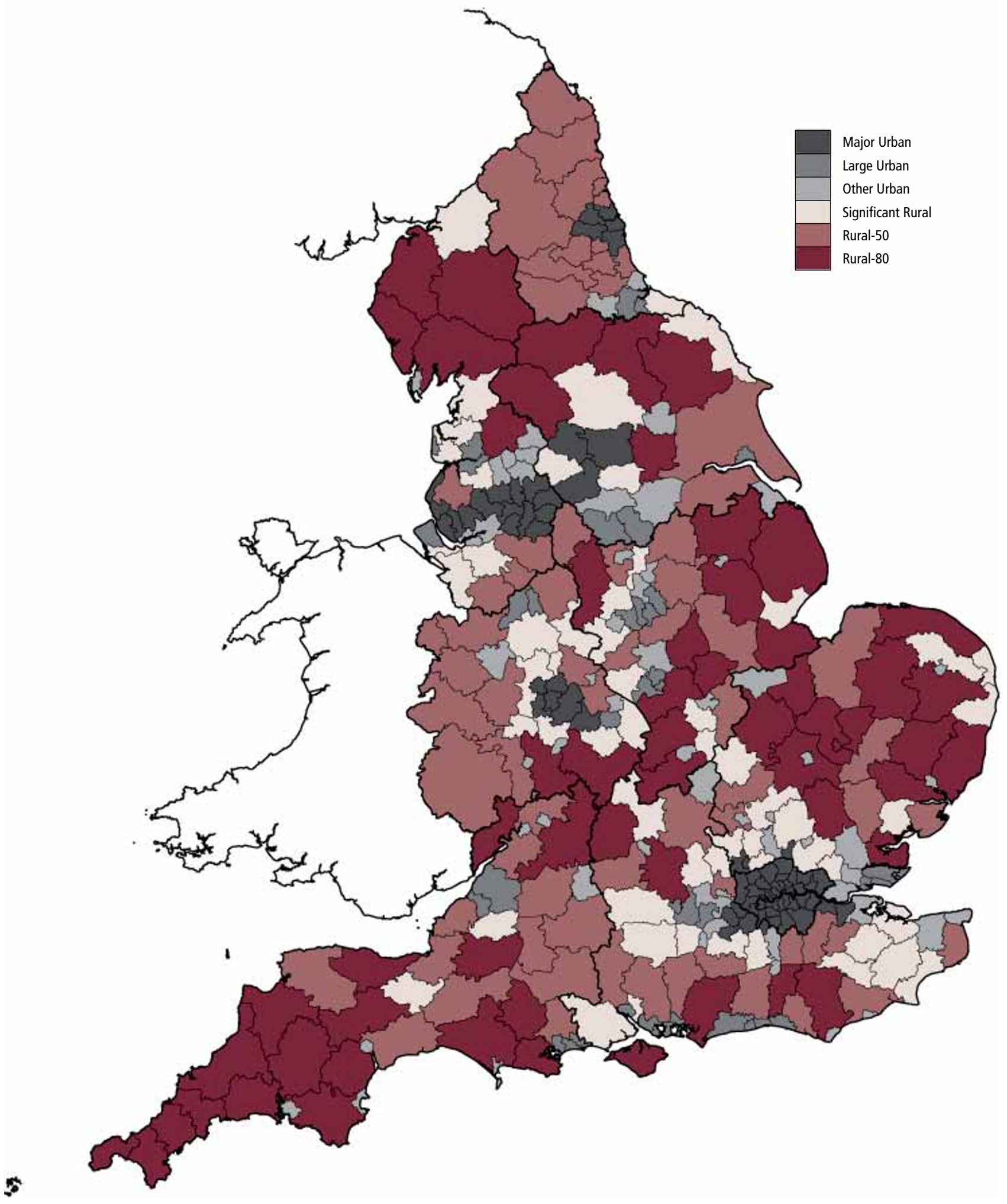


Rural and urban productivity: groups of regions

The nine Government Office Regions can be merged into three larger groups of regions: the Northern Way (the North West, North East and Yorkshire and the Humber), the Greater South East (London, South East and East of England) and Midlands and South West (East Midlands, West Midlands and the South West). Productivity can be indexed such that England=100, which gives an indication of how rural and urban economic performance compares inter-regionally (Figure 2). Estimates can also be indexed so that each regional grouping $=100$, which shows how rural and urban areas perform in the context of each regional group (Figure 3).

The latest estimates show that relative to the England average, the Greater South East has performed generally well with major urban districts, and unsurprisingly London in particular, having the highest relative productivity. Productivity in large urban areas is similar in the Greater South East and the Midlands and South West, but all the rural categories in the Greater South East outperform rural areas elsewhere. While across the Northern Way productivity is generally lower than elsewhere, interestingly its predominantly rural areas have higher productivity than those in the Midlands and South West.

When comparing productivity within each regional grouping (Figure 3), only rural-50 districts in the Northern Way, large urban in Midlands and Southwest and major urban districts and London in the Greater South East have productivity levels more than 5 per cent above their respective region's average productivity.

In the Northern Way, the rural-80, significant rural and major urban areas have slightly above regional average productivity levels. There is also no gap between productivity levels in these areas. In the Midlands and South West, the most extreme categories of the classification - major urban and rural-80 - have below-average productivity, with little variation in the other categories. In the Greater South East there is a significant productivity gap between major urban, London and other areas. While these two areas have above-average productivity, with the exception of significant rural areas all other categories in the Greater South East have productivity between ten and twenty percentage points below the regional average.

\section{Three-way rural-urban classification} To look at each region individually, the categories of the LA classification can be collapsed to form three, rather than six, groups (Figure 4). Relative to the England average, again London has the highest productivity in England. With the exception of the northern regions, significant rural areas tend to have relatively high productivity within each region. In South East, East of England and East Midlands regions there is little difference between the predominantly rural and urban areas. However, urban and rural productivity differences vary within other regions; in the South West and West Midlands, predominantly urban areas have higher productivity than predominantly rural areas, but in the North West and Yorkshire and the Humber the opposite is true, with productivity increasing with rurality.

\section{Three-year averages}

To avoid the issue of erratic estimates for the full six-way LA classification for each

\section{Figure 2}

\section{GVA per job by LA classification for regional grouping, 2006}

Indices (England=100)

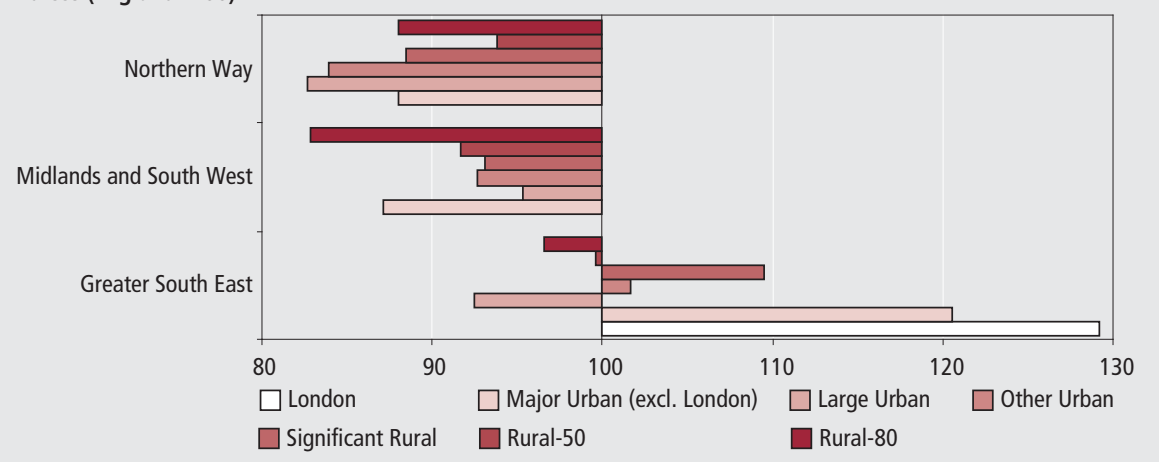

Source: Office for National Statistics

\section{Figure 3}

\section{GVA per job by LA classification for regional grouping, 2006}

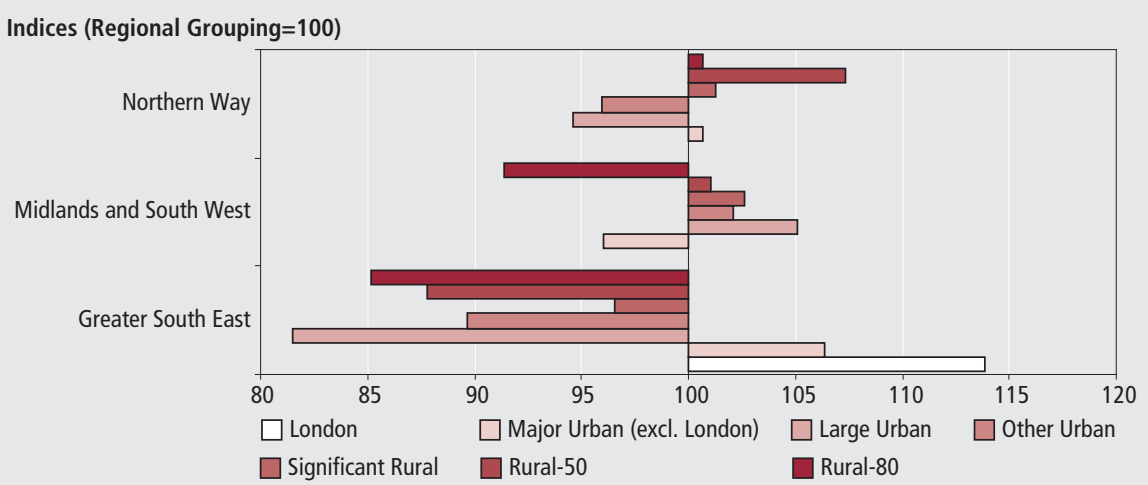

Source: Office for National Statistics

\section{Figure 4}

\section{GVA per job by three tier LA classification, 2006}

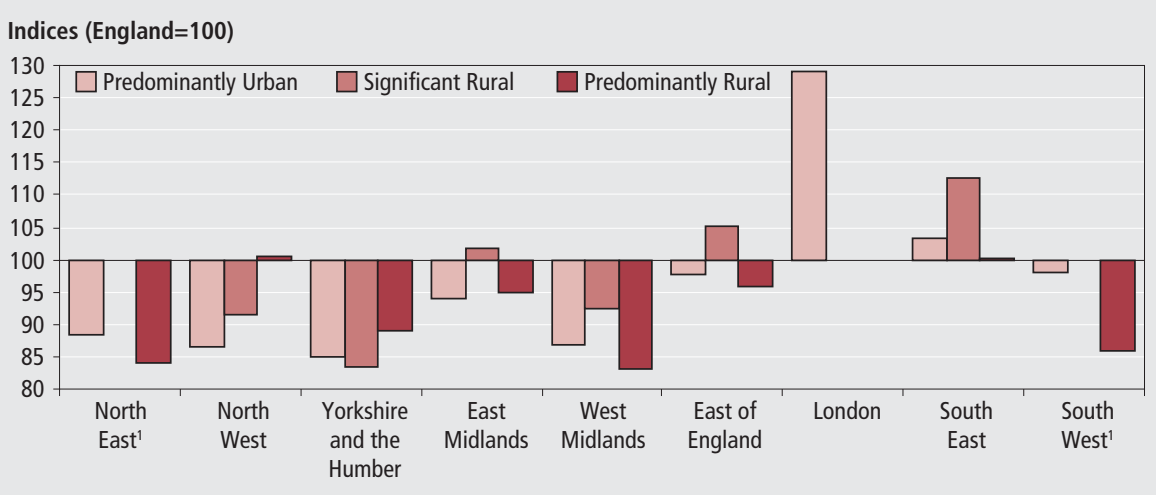

1 There are too few data points to produce estimates for significant rural areas for the North East and South West. 
region, an average of three years' GVA and workforce jobs data have been used to produce a full breakdown by region for each of the six categories of the LA classification. This produces more stable figures for estimates based on few data points and adds more detail to the 2006 estimates in Figure 4 . This increased detail provides an interesting insight into intra-regional productivity and shows the change over time between 2001-3 and 2004-6.

Figure 5 shows differences in productivity from the England average by the six-point urban-rural classification for each region in 2004-6. It is evident that relative to England, major urban districts in the South East, East of England, and London have productivity between 15 and 30 percentage points above average. There is possibly a relationship between proximity and accessibility to London and high urban productivity. The major urban areas in the South East and the East of England are all adjoining London (see Map1). The other urban categories of the LA classification in these regions do not show such high levels of productivity. Elsewhere there is little differential for major urban areas with productivity around 10 percentage points less than the England average.

Large urban and other urban areas display below average productivity across most regions with the exception of other urban in the South East and large urban in the South West, which are around 5 percentage points above national average.

The relatively high productivity in predominantly rural areas in the North West (Figure 4) is driven by high productivity in rural-50 areas (Figure 5) which is 20 percentage points higher than any other category in the region and 10 percentage points above national average productivity. Elsewhere, the productivity levels of rural-50 and significant rural areas vary considerably across the regions. Rural80 areas tend to have lower productivity than other types of areas in most regions (South West, South East, East Midlands, West Midlands and North West) although rural-80 areas in the East of England have higher relative productivity than all types of area in Yorkshire and the Humber and the West Midlands.

\section{Change over time}

For the purposes of this analysis changes greater than five percentage points are assumed to be significant. This follows a similar recommendation that the ONS uses when making international comparisons of productivity (see ONS Productivity Handbook). It should be noted that while these estimates are based on less erratic averages, they are still in some cases based on very few data points and should therefore be treated with caution.

Table 1 and Figure 6 illustrate how productivity differed and changed relative to the England average in the urban and rural parts of the regions in 2001-3 and 2004-6. The largest change between 2001-3 and 2004-6 by far is in significant rural areas (up by 15 percentage points) in the North East. It should be noted, however, this refers to just one local authority and as mentioned above the estimates may not be robust. The data shows that all the other areas in this region were below the national average in 2001-3 and deteriorated further relative to the average in 2004-06. In the North West rural-50 areas have seen a large increase in productivity relative to England between 2001-3 and 2004-6, with an increase of around ten percentage points. In contrast, significant rural districts have shown a decrease of seven percentage points, while other areas have remained reasonably stable. With the exception of rural-80 areas, all other types of area in Yorkshire and the Humber - and most notably major urban areas - showed a decrease in productivity and diverged further from the national average between 2001-3 and 2004-6.

In the Midlands and South West there was little significant change between the two time periods, except a 5 percentage

\section{Figure 5 \\ GVA per job by LA classification, 2004-2006}

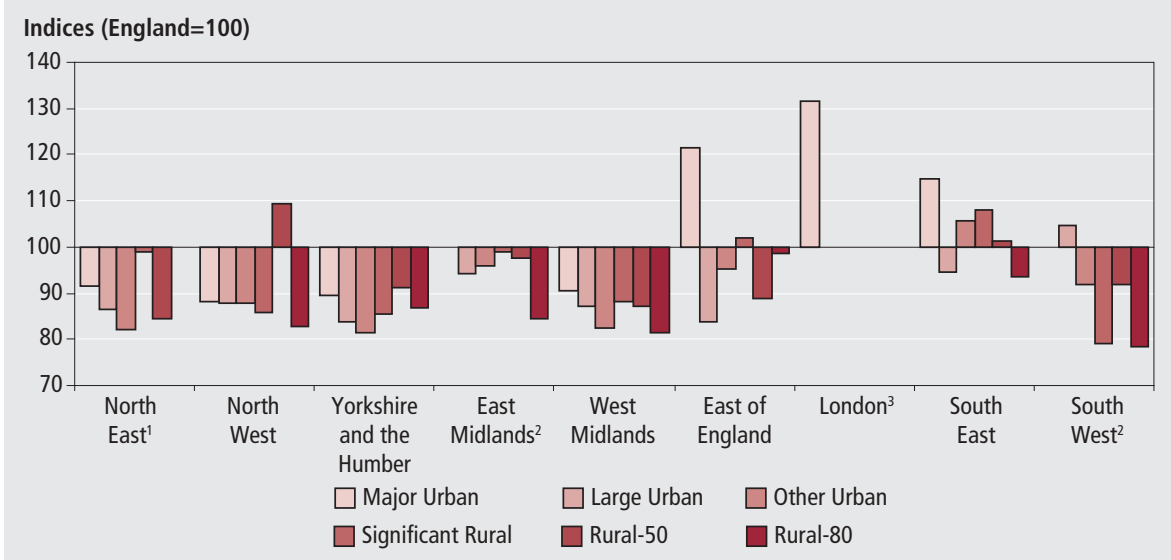

Notes:

Source: Office for National Statistics

1 There are no rural-80 areas in the North East.

2 There are no major urban areas in East Midlands and the South West.

3 London is made up entirely of major urban authorities.

Table 1

GVA per job by region and LA classification', 2001-2003 and 2004-2006 averages

Indices (England=100)

\begin{tabular}{|c|c|c|c|c|c|c|c|c|c|c|c|c|c|c|c|c|c|c|}
\hline & \multicolumn{2}{|c|}{ North East } & \multicolumn{2}{|c|}{ North West } & \multicolumn{2}{|c|}{$\begin{array}{l}\text { Yorkshire and } \\
\text { the Humber }\end{array}$} & \multicolumn{2}{|c|}{ East Midlands } & \multicolumn{2}{|c|}{ West Midlands } & \multicolumn{2}{|c|}{ East of England } & \multicolumn{2}{|c|}{ London } & \multicolumn{2}{|c|}{ South East } & \multicolumn{2}{|c|}{ South West } \\
\hline & $2001-3$ & $2004-6$ & $2001-3$ & $2004-6$ & $2001-3$ & $2004-6$ & 2001-3 & $2004-6$ & $2001-3$ & $2004-6$ & 2001-3 & $2004-6$ & $2001-3$ & $2004-6$ & $2001-3$ & $2004-6$ & $2001-3$ & $2004-6$ \\
\hline Major Urban & 94.4 & 91.6 & 89.4 & 88.1 & 94.9 & 89.5 & - & - & 95.8 & 90.4 & 127.5 & 121.3 & 130.8 & 131.4 & 108.1 & 114.7 & - & - \\
\hline Large Urban & 88.0 & 86.4 & 89.4 & 87.9 & 86.7 & 83.7 & 91.4 & 94.1 & 89.3 & 87.0 & 88.4 & 83.8 & - & - & 95.9 & 94.5 & 106.6 & 104.5 \\
\hline Other Urban & 87.4 & 82.2 & 88.5 & 87.9 & 84.4 & 81.4 & 97.9 & 95.8 & 83.7 & 82.4 & 90.5 & 95.4 & - & - & 104.7 & 105.8 & 94.4 & 91.9 \\
\hline Significant Rural & 83.1 & 98.8 & 93.0 & 85.9 & 86.8 & 85.4 & 96.2 & 98.8 & 88.8 & 88.1 & 95.1 & 102.0 & - & - & 105.2 & 107.9 & 81.1 & 79.0 \\
\hline Rural-50 & 87.9 & 84.4 & 98.9 & 109.5 & 92.3 & 91.1 & 97.3 & 97.5 & 85.6 & 87.1 & 97.0 & 89.0 & - & - & 97.7 & 101.2 & 89.4 & 91.8 \\
\hline Rural-80 & - & - & 82.4 & 82.7 & 84.0 & 87.0 & 86.9 & 84.6 & 80.8 & 81.4 & 94.7 & 98.8 & - & - & 93.9 & 93.4 & 74.1 & 78.3 \\
\hline
\end{tabular}

Note:

Source: Office for National Statistic

1 There are no major urban authorities in the South West and and East Midlands and no rural-80 areas in the North East. London is made up entirely of major urban authorities. 


\section{Figure 6}

GVA per job by region and type of area, 2001-2003 and 2004-2006

Indices (England $=100$ )

a)

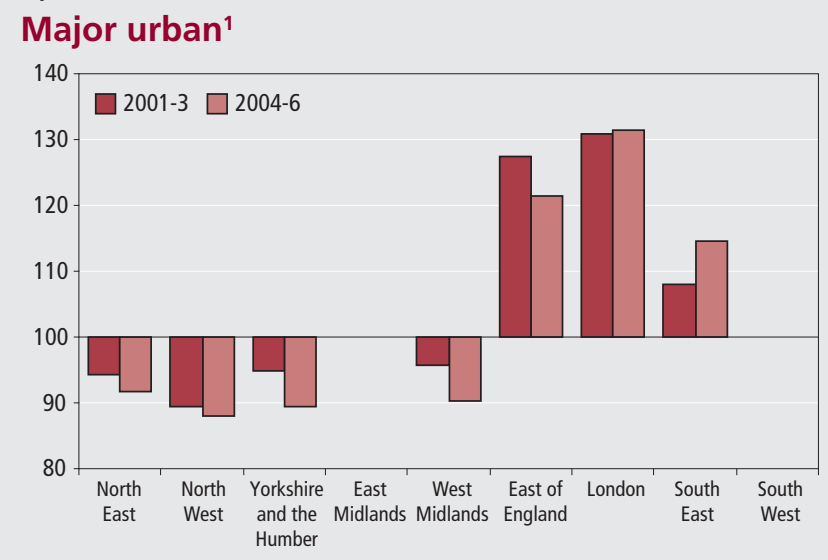

b)

\section{Large urban}

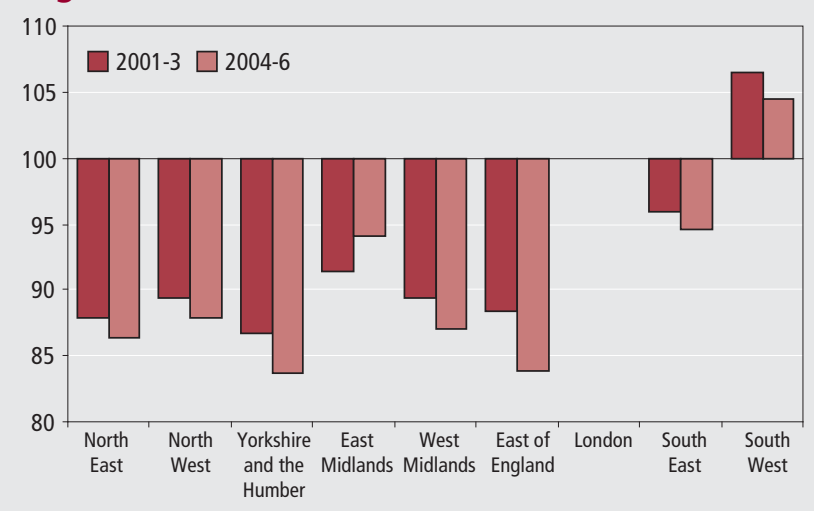

c)

\section{Other urban}

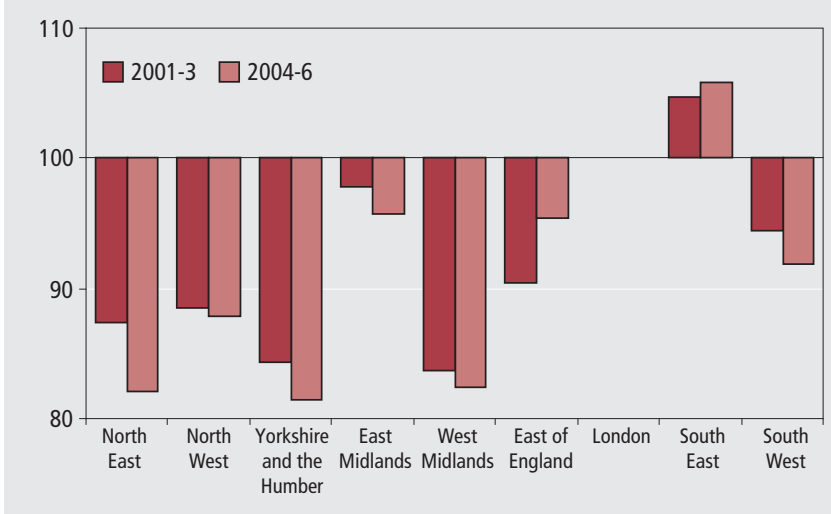

d)

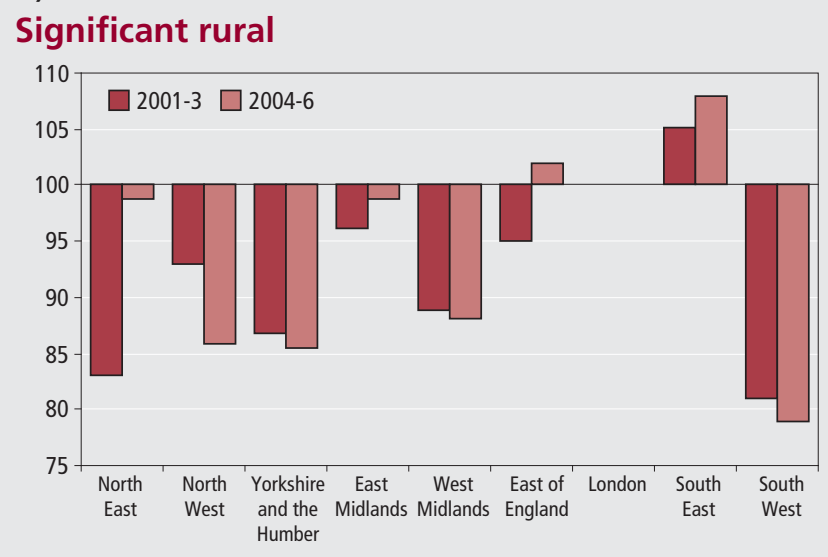

e)

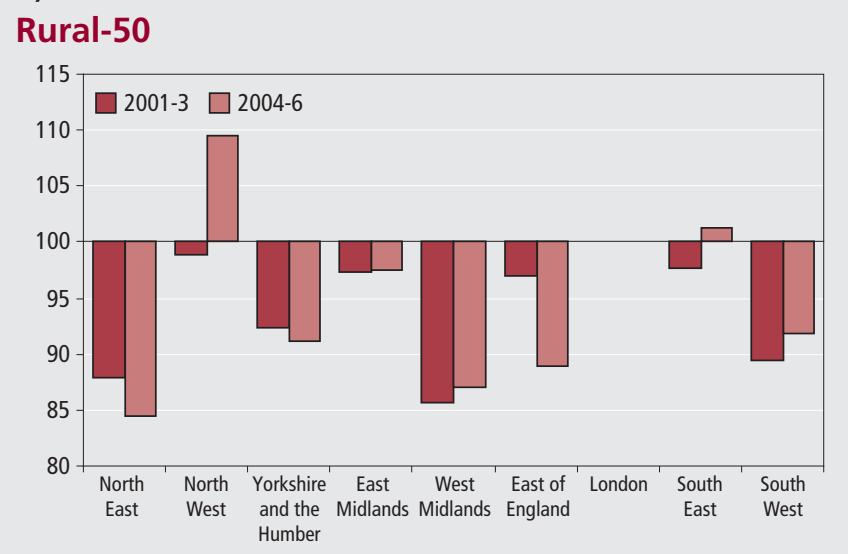

f)

\section{Rural-802}

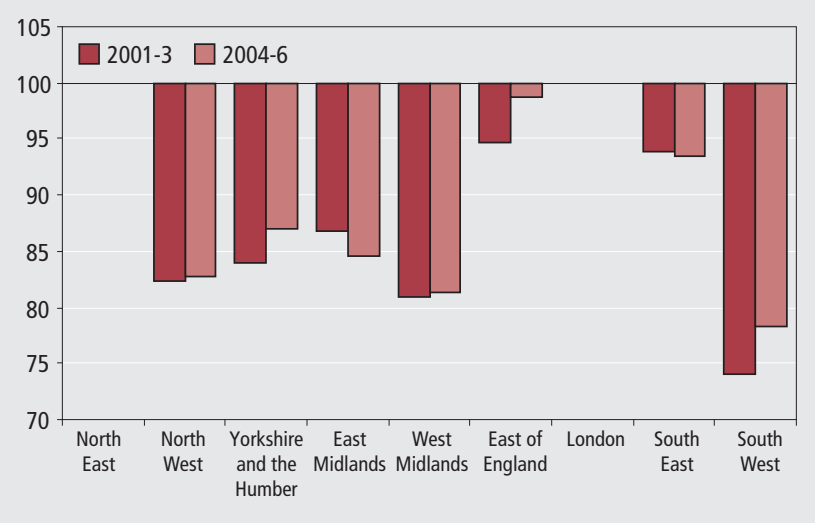

Notes:

Source: Office for National Statistics

1 There are no major urban authorities in East Midlands and the South West. London is made up entirely of major urban authorities.

2 There are no rural-80 areas in the North East.

point drop in West Midland's major urban areas between 2001-3 and 2004-6.

The largest positive change in productivity in the Greater South East region between 2001-3 and 2004-6 was in major urban areas in the South East and in significant rural areas in the East of England, which both increased by almost seven percentage points and were above national average. The second most significant improvement in productivity occurred in the other urban areas in the East of England where productivity improved over this period such that it is converging with the national average. Significant drops in productivity also occurred in the East of England with large and major urban and rural-50 regions declining further relative to the national average; they experienced five, six and eight percentage point decreases respectively.

Overall, across England the productivity in urban areas generally decreased between 2001-3 and 2004-6 except in major urban areas in the South East and London, and other urban areas in the Greater South East region. Productivity in major urban 
areas in the Greater South East region remains substantially higher than the national average productivity in 2004-6, however, while they continued to improve further in London and the South East, the productivity in these areas fell in the East of England. Similarly, the higher than average productivity in large urban areas in the South West in 2001-3 declined slightly in 2004- 6 while the above average productivity of other urban areas in the South East improved slightly over the same period.

Predominantly and significant rural areas, on the other hand showed mixed results. The productivity of rural80 regions increased in every region except in East Midlands and South East, although it remained below national average productivity in every region in both periods. It should be noted that the productivity of rural- 80 areas in the East of England appears to be catching up with the average productivity in England. In rural-50 areas, the North West and South East regions had the strongest performance; both increased during this time and were above the national average in 2004-6. The East of England had the biggest drop in rural-50 productivity during this period. The change in productivity in significant rural areas varied between a large increase in the North East ${ }^{1}$ and a significant drop in the North West. Productivity in significant rural areas improved further during this time and was above the national average in the Greater South East in 2004-6.

\section{Regional overview}

Key figures on a regional basis indicate that:

- in 2007 London was the region with the highest productivity, in terms of GVA per hour worked, at 30 percentage points above the UK average. Northern Ireland had the lowest productivity in 2007, at 16 percentage points below the UK average.

- between 2007 and 2008, the statistical value of goods exports grew by approximately 13 per cent in the UK as a whole. The highest growth occurred in the South East and Wales, at 19 per cent, while Scotland had the lowest growth at 4 per cent.

- the South East had the highest employment rate in the first quarter of 2009, at 78 per cent; Northern Ireland had the lowest rate, at 67 per cent, compared with the UK employment rate of 74 per cent.

- In the first quarter of 2009, the unemployment rate was highest in the West Midlands (9.3 per cent) and lowest in the South East (5.3 per cent). The unemployment rate increased in all regions over the year to the first quarter of 2009 .

\section{Headline indicators}

In order to gain an overview of the economic performance of UK regions, this article discusses a selection of economic indicators. Currently, the most widely used indicator of regional economic performance is Gross Value Added (GVA) per head. Policymakers frequently use GVA per head as a headline indicator of regional productivity and of regional incomes when comparing and benchmarking regions that differ in geographical size, economic output and population. However, as Dunnell (2009) has explained, productivity and income are very different concepts.

GVA per head is calculated as the simple ratio of the economic activity in a region divided by the number of people living in a region, while productivity is defined as the ratio of GVA divided by the labour input (jobs or hours worked) used to create it. GVA per head does not take account of:

- people commuting in and out of regions to work

- regional differences in the percentages of residents who are not directly contributing to GVA, such as young people or pensioners, and

- different labour market structures across regions, such as full- and part-time working arrangements

Therefore, GVA per hour worked or GVA per filled job are more appropriate productivity indicators. It needs to be noted that these indicators also depend on pricing thus productivity can fall/rise with decreasing/increasing prices. As regional price deflators do not yet exist, GVA estimates used in productivity figures are in nominal, not real terms, therefore it is not possible to isolate volume changes from price changes.

Similarly, Gross Disposable Household Income (GDHI) per head is a better measure of regional incomes than GVA per head. For example, due to commuting, residents might derive their incomes from economic activity in another region, which is not captured by GVA per head of their region. They may also have sources of income which are unrelated to current work, such as pensions and investment incomes.

\section{Regional performance}

GVA is a good measure of the economic output of a region. In December 2008, ONS published GVA estimates for 2007 and revised estimates for previous years. Table 2 shows the regional economic performance in terms of workplace-based GVA and GVA per head and their respective average annual growth over the period 2000 to 2007. Although GVA per head is not a good indicator of regional productivity or income, it does take account of variations in geographical size among UK regions and therefore allows better comparisons than using GVA in total.

The estimates show that London had the highest GVA ( $£ 250$ billion) and GVA per head $(£ 33,100)$ in 2007 , followed by the South East ( $£ 175$ billion and $£ 21,100$, respectively). The North West generated the third highest GVA ( $£ 121$ billion), but was seventh in terms of its GVA per head $(£ 17,600)$. Northern Ireland and the North East had the lowest GVA in 2007, while Wales and the North East had the lowest GVA per head.

In terms of average annual percentage growth of GVA between 2000 and 2007, the East Midlands, London, Northern Ireland and the East of England had the highest GVA growth, while the West Midlands and Wales had the lowest. Average annual percentage growth of GVA per head was highest in Scotland, London, Northern Ireland and the North East, while the West Midlands, Yorkshire and The Humber and Wales grew slowest.

\section{Labour productivity}

To compare regions in terms of productivity, GVA per hour worked is the preferred indicator. At lower levels of geography, 'hours worked' estimates are not yet available and GVA per filled job should be used. These two measures of productivity divide GVA by the labour input, namely hours worked in all jobs or the number of jobs used to create it.

GVA per hour worked and GVA per filled job take account of commuting effects and different age profiles, and the former also accounts for variations in labour market structures, such as full- and parttime working arrangements and job share availability.

On 11 February 2009, productivity estimates for 2007 and revised estimates for previous years were published. These estimates make use of the GVA figures presented in Table 2, and updated 'filled jobs' and 'hours worked' estimates.

It should be noted that the productivity 
Table 2

Workplace-based gross value added and gross value added per head at current basic prices: by NUTS1 region

\begin{tabular}{|c|c|c|c|c|c|c|c|c|c|c|c|c|c|}
\hline & UK $^{1}$ & $\begin{array}{r}\text { North } \\
\text { East }\end{array}$ & $\begin{array}{r}\text { North } \\
\text { West }\end{array}$ & $\begin{array}{l}\text { Yorkshire } \\
\text { and The } \\
\text { Humber }\end{array}$ & $\begin{array}{r}\text { East } \\
\text { Midlands }\end{array}$ & $\begin{array}{r}\text { West } \\
\text { Midlands }\end{array}$ & $\begin{array}{l}\text { East of } \\
\text { England }\end{array}$ & London & $\begin{array}{r}\text { South } \\
\text { East }\end{array}$ & $\begin{array}{l}\text { South } \\
\text { West }\end{array}$ & Wales & Scotland & $\begin{array}{l}\text { Northern } \\
\text { Ireland }\end{array}$ \\
\hline \multicolumn{14}{|l|}{ GVA (f million) } \\
\hline 2000 & 842,500 & 28,300 & 84,700 & 61,400 & 52,600 & 68,400 & 72,300 & 169,000 & 123,300 & 64,200 & 31,700 & 67,200 & 19,500 \\
\hline $2007^{2}$ & $1,216,900$ & 40,300 & 120,500 & 87,200 & 78,100 & 92,200 & 107,000 & 250,100 & 175,300 & 94,200 & 44,300 & 98,900 & 28,800 \\
\hline $\begin{array}{l}\text { Average annual } \\
\text { percentage growth } \\
2000-2007^{2}\end{array}$ & 5.4 & 5.2 & 5.2 & 5.1 & 5.8 & 4.4 & 5.8 & 5.8 & 5.2 & 5.6 & 4.9 & 5.7 & 5.7 \\
\hline \multicolumn{14}{|l|}{ GVA per head $(\mathrm{f})$} \\
\hline 2000 & 14,300 & 11,100 & 12,500 & 12,400 & 12,600 & 13,000 & 13,500 & 23,400 & 15,400 & 13,100 & 10,900 & 13,300 & 11,600 \\
\hline $2007^{2}$ & 20,000 & 15,700 & 17,600 & 16,900 & 17,700 & 17,100 & 18,900 & 33,100 & 21,100 & 18,200 & 14,900 & 19,200 & 16,400 \\
\hline $\begin{array}{l}\text { Average annual } \\
\text { percentage growth } \\
2000-2007^{2}\end{array}$ & 4.9 & 5.1 & 5.0 & 4.5 & 5.0 & 4.0 & 4.9 & 5.1 & 4.6 & 4.8 & 4.6 & 5.4 & 5.1 \\
\hline
\end{tabular}

\section{Notes:}

1 UK less Extra-regio and statistical discrepancy.

2 Provisional.

figures presented here use unsmoothed

GVA as their output measure as opposed to headline GVA, which is calculated as a five-year moving average. The unsmoothed measure is used to ensure consistency with the labour input data (Dey-Chowdhury et al 2008), but raises some concerns about increased volatility of productivity estimates compared to those based on headline GVA. The question of whether to smooth productivity figures after dividing unsmoothed GVA by labour data, and presenting these as headline estimates, is one which will be addressed by ONS in the coming months.

Figure 7 shows that in 2007 GVA per filled job and GVA per hour worked exhibited smaller differences from the UK average than the catch-all indicator GVA per head. This is mainly due to commuting patterns. London, for example, has a very high GVA per head, mainly due to incoming workers generating a high GVA, which is then divided by a much lower resident population. Productivity indicators, on the other hand, divide regional GVA by the jobs or hours worked used to create it.

Figure 8 shows the regional GVA per hour worked productivity index on a time series basis from 2001 to 2007. In 2007, London, the South East and the East of England were the only three regions with a productivity performance above the UK average. The East of England saw the strongest improvement in its relative performance from 2001 to 2007 from below the UK average to above average in 2007. London also improved its relative performance, therefore diverging further from the UK average. Relative productivity in the South East remained roughly constant. Northern Ireland and Wales had the lowest relative productivity in 2007. The strongest divergence from the UK average productivity between 2001 and 2007 was experienced in the North East, Wales and Yorkshire and The Humber. This implies that these regions' productivity grew by less than the UK average, therefore widening the productivity gap between regions.

The previous section discussed the economic activity and productivity in the regions. This section discusses regional incomes, which gives an indication of the welfare of residents living in a region.

Gross disposable household income

\section{Figure 7}

Comparison of regional economic indicators: by NUTS1 region, 2007

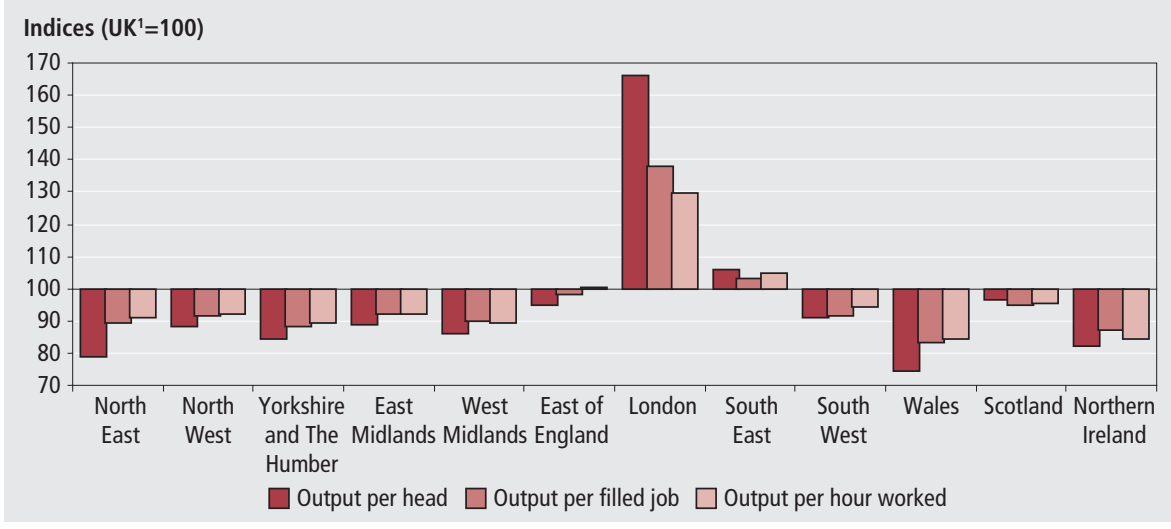

Note:

Source: Office for National Statistics

1 UK less Extra-regio statistical discrepancy.

\section{Figure 8}

GVA per hour worked: by NUTS1 region

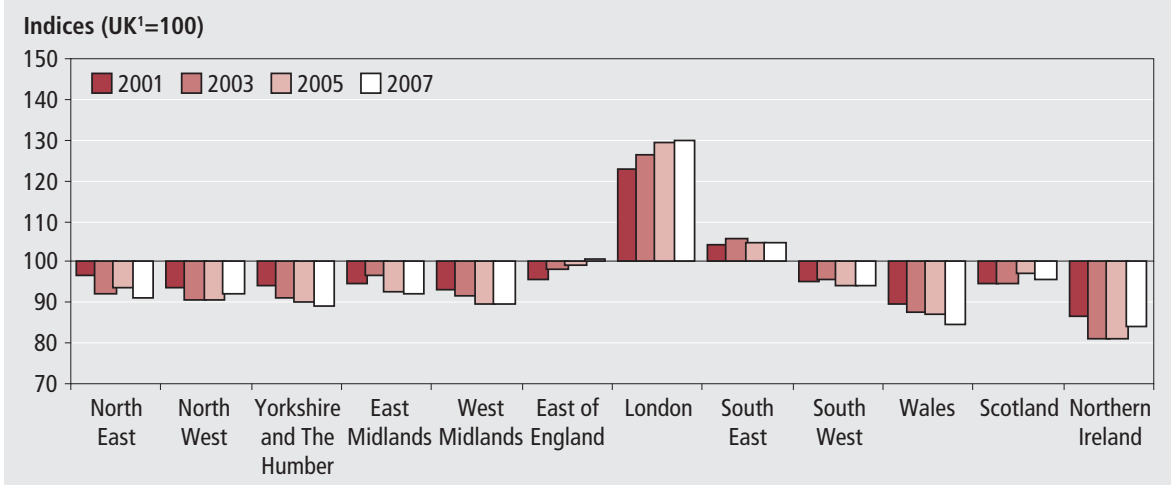

1 UK less Extra-regio statistical discrepancy. 
(GDHI) represents the amount of money available to households after taxes, National Insurance and pension contributions, property costs and other interest payments have been deducted. The estimates of GDHI, however, are at current basic prices and so do not take inflation effects or regional price differences into account.

In order to make reliable comparisons of regional income levels, the analysis needs to take account of relative sizes of regions. Therefore, GDHI per head, which is a residence-based measure, is used as an indicator of the welfare of people living in the region.

The May 2009 edition of this article discussed the latest data on GDHI in detail, therefore this section presents a brief overview of those analysis. Figure 9 presents indices of GDHI per head for 2001, 2003, 2005 and 2007, showing movements in regional household income relative to the UK average over time. It is evident that the GDHI per head is above the UK average only in the regions of the 'Greater South East'. Of these regions, London has consistently had the highest GDHI per head since 2001 and is diverging from the national average. The South East and East of England, on the other hand, are getting closer to the national average as they experienced the lowest growth in household income compared to other regions between 2001 and 2007. Similarly, improvements against the national average are evident in most regions with lower household income, particularly the North East and the devolved administrations. This implies greater parity across regions in terms of household income.

Comparing these outcomes with the regional productivity performance shown in Figure 8 shows that, unlike income per head, productivity has been diverging from the UK average in most regions. Moreover, some regions have been performing close to the average in terms of productivity, while their income per head shows stronger divergences from average. The North East, for example, has had a close to average but declining productivity performance since 2001 and at the same time the lowest, but improving, income per head. One reason for this might be the region's low employment and high unemployment rates (see labour market section).

Gross median weekly earnings represent another indicator of regional welfare.

Figure 10 shows the gross median weekly pay for all full-time employees, split into female and male full-time employees, in each region in April 2008.
As in previous years, London was the region with the highest gross median weekly pay, at $£ 612.70$, followed by the South East, at $£ 499.80$. These were the only regions above the UK average of $£ 478.60$. Northern Ireland (£417.60), the North East (£420.60) and Wales (£421.00) recorded the lowest earnings in April 2008.

Females across the UK regions received lower pay than males. In Northern Ireland, the discrepancy was smallest, while it was largest in London and the South East. The weekly pay for male full-time employees was above the UK average for all full-time employees in nine of the 12 NUTS1 regions, while the weekly pay of female full-time employees was only above the UK average in London. However, in terms of annual average percentage growth between 2004 and 2008, pay for females outperformed that for males. The only regions where pay for females did not grow more than male pay over this period were Yorkshire and the Humber, South East and Scotland. The difference in growth rates, however, was marginal. The first two regions had only a 0.1 percentage point difference in growth rates between male and female pay and Scotland had a 0.2 percentage point difference. It is interesting to note that Scotland had the highest annual average growth rate, both for males and females, among the regions over the period considered above.

\section{Drivers of productivity}

HM Treasury and BERR have identified five key drivers of productivity - investment, innovation, enterprise, competition and skills - that can help explain differences in productivity across regions.

Alongside these five key drivers, other factors, such as connectivity, industrial structure and region-specific assets can have a strong influence on regional productivity performance.

This article uses expenditure on Research and Development (R\&D) by businesses as a measure of innovation; the numbers of business births and deaths and survival

\section{Figure 9}

\section{Headline gross disposable household income per head: by NUTS1 region}

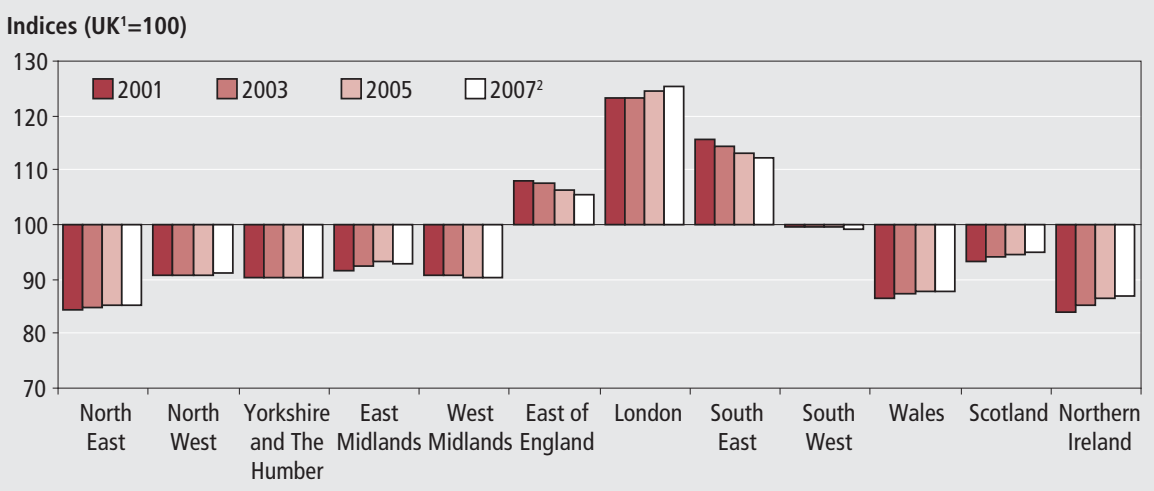

\section{Notes:}

Source: Office for National Statistics

1 UK less Extra-regio.

2 Provisional.

\section{Figure 10}

Gross median weekly pay of full-time employees: by NUTS1 region, April 2008

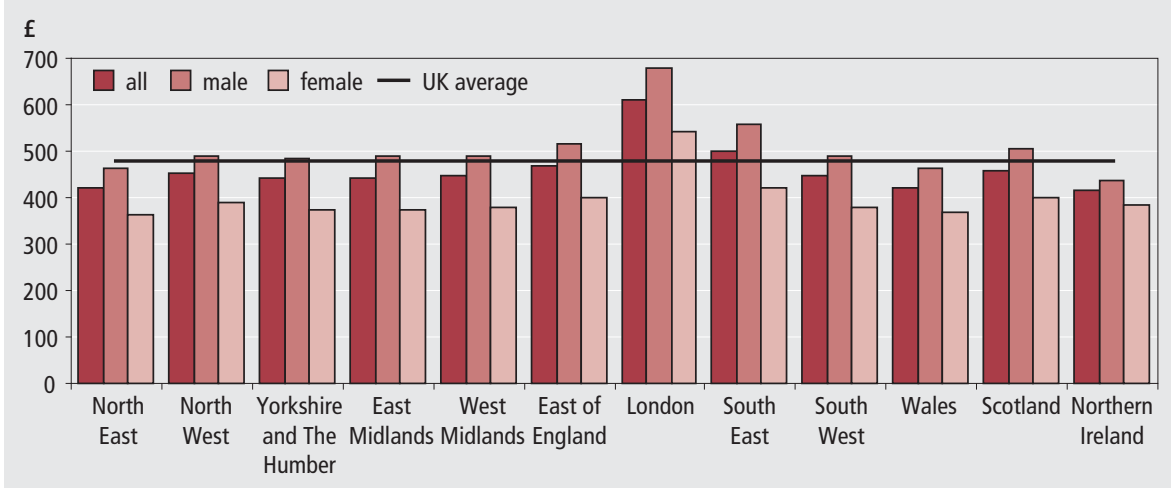

Source: Annual Survey of Hours and Earnings, Office for National Statistics 
rates as an indicator for enterprise; UK regional trade in goods serves as a measure of competition; and the qualifications of the current working-age population and those of young people, who represent the future workforce, to provide an indicator for the skills driver.

\section{Investment}

Investment in physical capital, such as machinery, equipment and buildings, enables workers to produce more and higher quality output. Therefore, investment can have a significant positive impact on productivity. Due to quality concerns regarding the regional allocations of investment, which is recorded at the level of the enterprise and not at the local level, this article does not currently include data on investment.

Nevertheless, as Dunnell (2009) has pointed out, inflows of foreign direct investment (FDI) projects and estimated numbers of associated jobs by region can serve as a narrow indicator of investment. However, FDI does not cover all investment in a region and there is no requirement to notify UK Trade \& Investment when undertaking FDI.

\section{Innovation}

Innovation is a necessary, although not sufficient, condition for economic success and is therefore recognised as an important driver of productivity. Innovation comprises, among others, the development of new technologies that increase efficiency and the introduction of new, more valuable goods and services. It also includes intangibles such as new methods of working and improvements to services.

$R \& D$ represents one of the determinants to the innovation process and is defined by the Organisation for Economic Cooperation and Development (OECD) in its Frascati Manual, which proposes a standard practice for surveys on $\mathrm{R} \& \mathrm{D}$, as 'creative work undertaken on a systematic basis in order to increase the stock of knowledge, including knowledge of man, culture and society, and the use of this stock of knowledge to create new applications' The OECD definition of R\&D covers the following:

- basic research: experimental and theoretical work to obtain new knowledge of the underlying foundation of phenomena and observable facts, without any particular application or use in view

- applied research: work undertaken to acquire new knowledge, which is directed primarily towards a specific practical aim, and

- experimental development: systematic work, drawing on existing knowledge, which is directed at producing new materials, products or devices, installing new processes, systems and services, or at improving substantially those already produced or installed

The OECD definition excludes education, training and any other related scientific, technological, industrial, administrative or supporting activities. However, innovation depends on a wider set of inputs than R\&D, including skills training, design, software and organisational investment by firms. HM Treasury Economics Working Paper No. 1 quantifies these broader knowledge economy inputs at UK level; more work is needed before these factors can be measured effectively at regional level.

Figure 11 presents statistics on Business Expenditure on Research and Development (BERD), which are consistent with internationally agreed standards. Figures for 2007 published on 30 January 2009 show business expenditure on $\mathrm{R} \& \mathrm{D}$ as a percentage of workplace-based GVA in 2001, 2003, 2005 and 2007. This is a measure commonly used in regional comparisons as it takes account of the size of regional economies. The figure shows that, since 2001, the East of England has been the region with by far the highest percentage of R\&D expenditure in terms of GVA, with 4.1 per cent in 2007. The South East had the second highest percentage (2.0 per cent), which has, however, been declining since 2001.

$\mathrm{R} \& \mathrm{D}$ expenditure as a share of regional GVA was 1.8 per cent in the North West and 1.3 per cent in the East Midlands and the South West. London, Yorkshire and The Humber and the three Devolved Administrations of Wales, Scotland and Northern Ireland had the lowest shares in 2007, at around 0.5 per cent each. London's very low share of expenditure on $R \& D$ does not necessarily suggest low levels of innovation but may due to it having a large concentration of service industries, which may be less R\&D intensive (within the OECD definition) if, for example, they rely heavily on human capital. It may also reflect the choice business make over locating their R\&D.

Approximately three quarters of the R\&D expenditure in the UK was made in the manufacturing sector in 2007.

Figure 12 shows that in most regions except in the Greater South East and West Midlands the share of the R\&D expenditure on manufacturing was over 80 per cent of their respective expenditure. East of England accounted for 27 per cent of the total R\&D expenditure in the UK in 2007 and had the highest level of R\&D expenditure on both the manufacturing and services. This may suggest that some London R\&D occurring in the surrounding regions.

\section{Enterprise}

Enterprise is another driver of productivity. It is defined as the seizing of new business opportunities by both start-ups and existing firms. New enterprises can bring innovative processes and technologies to the market, forcing existing ones to improve their productivity in order to remain competitive.

The February 2009 edition of this article focused on business demography in UK regions, using the newly published ONS series of enterprise births and deaths, which includes enterprises registered for

\section{Figure 11
Business expenditure on R\&D as a percentage of workplace-based GVA: by NUTS1 region

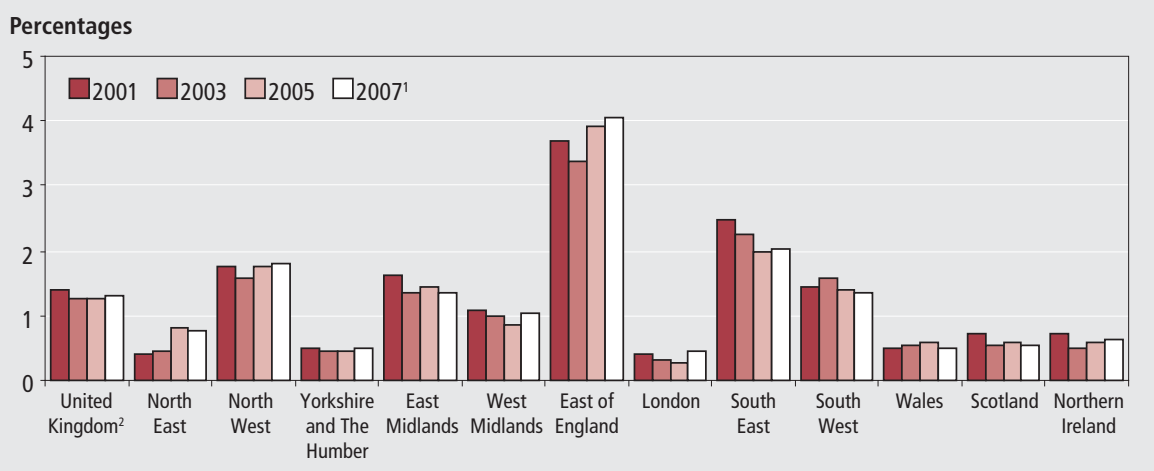

Notes:

1 Provisional.

2 UK less Extra-regio and statistical discrepancy.
Source: Regional Accounts and Business Expenditure on Research \& Development, Office for National Statistics 


\section{Figure 12 \\ Business expenditure on R\&D by NUTS1 region, 2007: broad industry groups}

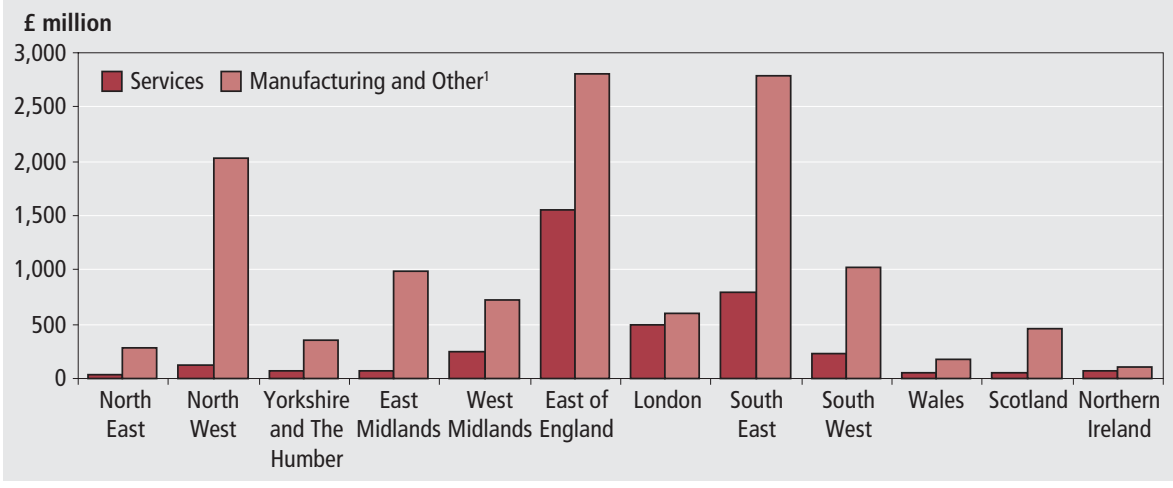

Note:

Source: Office for National Statistics

1 Other includes agriculture, hunting and forestry, fishing, extractive industries, electricity, gas and water supply and construction. The total expenditure on other industries across the UK was less than 2 per cent.

\section{Figure 13}

Enterprise births, deaths ${ }^{1}$ and net change as percentages of enterprise stock: by NUTS1 region, 2007

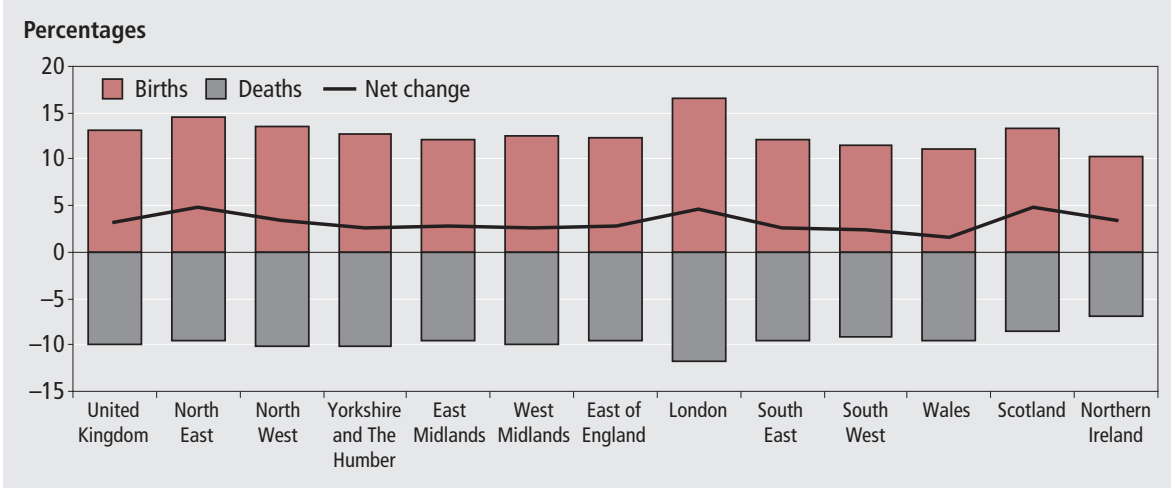

Note:

Source: Business Demography, Office for National Statistics

1 Provisional.

\section{Figure 14}

\section{Percentage of enterprises surviving three years: by year of birth and NUTS1 region}

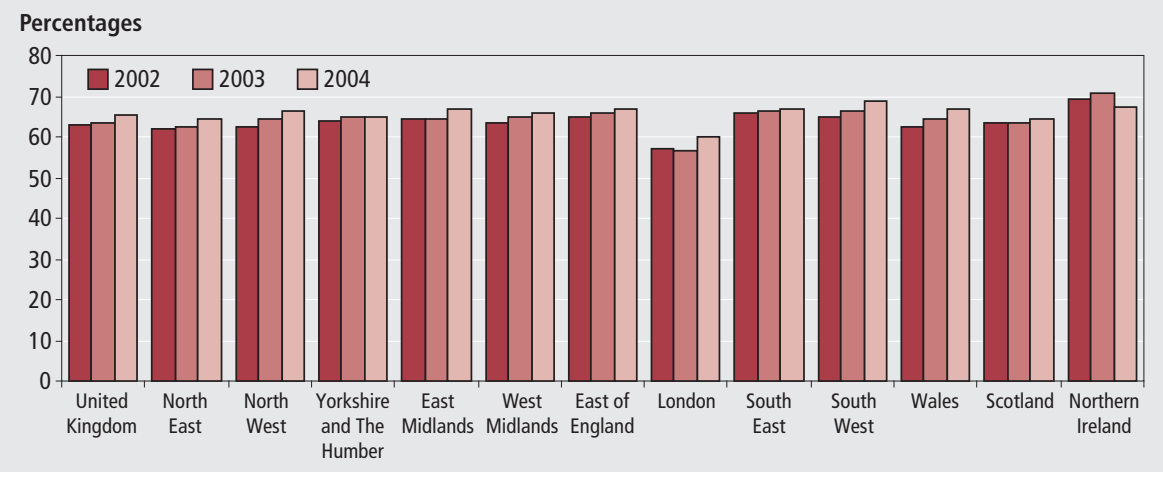

Source: Business Demography, Office for National Statistics

VAT and also those registered for payas-you-earn (PAYE). It needs to be noted that enterprise statistics relate to the place of registration of the enterprise, even though the enterprise may consist of more than one local unit, possibly in different regions.
Figure 13 shows the number of births and deaths of enterprises as a proportion of the active enterprise stock in 2007. The difference between the two represents the net change, which is calculated as a proportion of total stock. The figure shows that the North East and Scotland had the highest rate of net change, at 4.8 per cent, closely followed by London, at 4.7 per cent. Wales and the South West had the lowest rates, at 1.6 and 2.3 per cent, respectively. These rates were mainly driven by small enterprises with less than 5 employees which is approximately 80 percent of the total enterprise stock. Among the 5 per cent of the enterprises that have more than 20 employees, however, the net change was negative in every region. In the category of enterprises with employment size 1019 which comprises 6 percent of the total stock, the net change was also negative in every region with the exception of Scotland.

In 2007, across regions, the relatively modest net changes were the result of much larger proportions of enterprises joining and leaving the stock. These proportions were largest in London, followed by the North East. A relatively large proportion of enterprises joining and leaving the stock can be seen as desirable, as new enterprises entering the market are considered to bring innovative processes and technologies that drive up productivity and force unproductive enterprises to leave the market.

As well as analysing births and deaths of enterprises, it is useful to look at how long these enterprises survive. The Business Demography series contains data showing the number of years survived by enterprises born in the years 2002 to 2006 .

Figure 14 shows the proportion of enterprises born in 2002, 2003 and 2004 that survived for at least three years each. It shows that, overall in the UK, survival rates increased over the period, rising from 63 per cent of enterprises born in 2002 to 65 per cent of those born in 2004.

Patterns were similar across regions, with all but Northern Ireland having higher survival rates for enterprises born in 2004 than in 2002. Northern Ireland saw a fall from 69 to 67 per cent; however, this was still higher than the UK average of 65 per cent. Among enterprises born in 2004, those in the South West had the highest three year survival rate, at 69 per cent.

London stands out as the region with the lowest rate, at 60 per cent. Figure 13 has shown that London had the highest percentage of births and deaths of enterprises; therefore, it is not surprising that survival rates were relatively low. They could be an indication of London's ability to exploit short-term business opportunities. At the same time, it may suggest that many of the new enterprises born will not provide long-term growth and employment. 


\section{Competition}

Vigorous competition enhances productivity by creating incentives to innovate and ensure that resources are allocated to the most efficient firms. It also forces existing firms to organise work more effectively through imitations of organisational structures and technology. One indicator of competition is the volume of exports. Even though exports do not represent competition within a region, they still provide an indication of how international regions are in their outlook, and how able they are to face global competition.

HM Revenue \& Customs (HMRC) publishes statistics on regional trade in goods to the EU and non-EU destinations by statistical value. Trade in goods by definition excludes trade in intangibles and services. The statistical value of export trade is calculated as the value of the goods plus the cost of movement to the country's border.

Table 3 presents the latest quarterly estimates up to 2009 Q1 and includes full-year figures for 2007 and 2008. The total value of UK goods exports to all destinations increased by approximately 13 per cent between 2007 and 2008. South East and Wales delivered the highest growth rate in this period, rising by 19 per cent. The North East, at 18 per cent recorded the second highest growth rate in goods exports. At the other end of the scale, Scotland, at 4 per cent had the lowest growth rate. East Midlands had the second lowest growth rate (5 per cent).

As the European Union (EU) is the main export destination for UK goods, the table separates exports to EU and non-EU destinations. In the UK as a whole, the value of exports to the EU grew by 11 per cent in 2008. With the exception of East Midlands (down by 2 per cent) and Scotland (down by 1 per cent), all the regions recorded increases in the value of goods exports to the EU. London and the North East reported the highest growth, at 15 per cent.

The value of the UK exports to the rest of the world grew by 16 per cent in 2008 , with South East leading the way, up 31 per cent in value. With 21 percent increase in the value of exports to non-EU countries, North East had the second highest growth rate in England.

In terms of the latest estimates (2009 Q1), the value of goods exports to all destinations fell in every region except North West (up by 2 per cent) compared to the same quarter last year. West Midlands (down by 29 per cent) recorded the highest fall in total exports, followed by North East (down by 18 per cent) and Yorkshire and the Humber (down by 17 per cent). While all the regions except London had a decrease in the value of exports to the $\mathrm{EU}$, the fall in the value of non-EU exports masks wide regional variation. Half of the regions experienced a decline compared with the same quarter last year, while export values grew in the other half, with individual performances ranging from a contraction of 34 per cent in West Midlands to an increase of 21 per cent in Wales.

The figures also show a continuing downward trend in the value of total goods exports beginning in the third quarter of 2008. This may partly reflect the inherent volatility of quarterly trade data, although such declines appear to be consistent with intensifying global financial and economic crises in the second half of 2008. This downward trend is also evident for the EU exports for all the regions. Again, falling export values are most likely to be the product of the ongoing recession. The number of exporters in the UK for 2009 Q1 compared with the same quarter last year, decreased by 0.4 per cent, with London having the largest decrease of 2.5 per cent ${ }^{2}$

Figure 15 shows the value of exports of goods as a percentage of workplacebased regional GVA in 2000 and 2007, which takes account of the differing sizes of regional economies. In 2007, exports from the North East accounted for the highest percentage of GVA (24 per cent), 6 percentage points above the UK average. The region where exports accounted for the smallest percentage of GVA in 2007 was London, at 9 per cent. It needs to be noted that these figures show exports of goods as a percentage of headline GVA which also includes services and therefore is likely to underestimate the performance of some regions with a large share of services industries such as London.

In terms of this indicator's change over time, in all regions, except Yorkshire and The Humber, exports accounted for a smaller percentage of GVA in 2007 than in 2000. Scotland experienced the most significant drop from 2000 to 2007 , with exports in 2007 accounting for 16 percentage points less in terms of GVA than in 2000. Most other regions also experienced a decline from 2000 to 2004 , with some recovery in 2005 and 2006. In 2007, most regions saw their exports as a percentage of GVA fall.

\section{Skills}

The skills of workers influence productivity as they define the capabilities that the labour force can contribute to the production process. The concept of skills includes attributes of the workforce, such as 'softer' or interpersonal skills, which are difficult to measure or to compare in different situations or over time. Therefore, qualifications are often used as proxy indicators. By examining the qualifications, such as degree or equivalent, of the current workforce as well as those of young people, who represent the future capabilities of the labour market, a view of how skills are changing over time and their potential impact on productivity can be analysed. However, as characteristics of local economies dictate which labour skills are required, comparability between regions might be difficult. An alternative approach is to compare the percentage of the working-age population that has no recognised qualifications.

Figure 16 shows the proportion of the working-age population that has no

\section{Figure 15}

\section{Value of total export goods as a percentage of workplace-based GVA: by NUTS1 region}

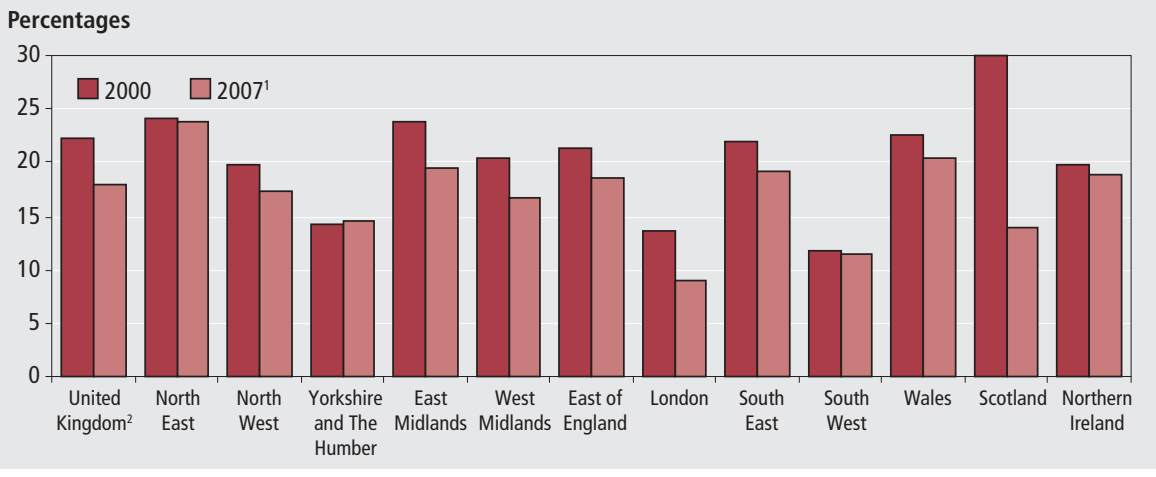

Notes:

1 Provisional.

2 UK less Extra-regio and statistical discrepancy.
Source: HM Revenue \& Customs, Regional Trade Statistics and Office for National Statistics 
Table 3

UK regional trade in goods - statistical value of exports: ${ }^{1}$ by NUTS1 region

f million

\begin{tabular}{|c|c|c|c|c|c|c|c|c|c|c|c|c|c|}
\hline Exports & $\begin{array}{r}\text { United } \\
\text { Kingdom }\end{array}$ & $\begin{array}{r}\text { North } \\
\text { East }\end{array}$ & $\begin{array}{r}\text { North } \\
\text { West }\end{array}$ & $\begin{array}{c}\text { Yorkshire } \\
\text { and The } \\
\text { Humber }\end{array}$ & $\begin{array}{r}\text { East } \\
\text { Midlands }\end{array}$ & $\begin{array}{r}\text { West } \\
\text { Midlands }\end{array}$ & $\begin{array}{l}\text { East of } \\
\text { England }\end{array}$ & London & $\begin{array}{r}\text { South } \\
\text { East }\end{array}$ & $\begin{array}{r}\text { South } \\
\text { West }\end{array}$ & Wales & Scotland & $\begin{array}{r}\text { Northern } \\
\text { Ireland }\end{array}$ \\
\hline \multicolumn{14}{|l|}{ EU Exports } \\
\hline 2007 Q1 & 31,748 & 1,303 & 2,794 & 1,765 & 2,296 & 2,267 & 3,164 & 2,244 & 4,598 & 1,725 & 1,440 & 1,569 & 847 \\
\hline 2007 Q2 & 31,265 & 1,287 & 2,952 & 1,696 & 2,036 & 2,325 & 2,998 & 2,066 & 4,609 & 1,581 & 1,415 & 1,636 & 850 \\
\hline 2007 Q3 & 30,663 & 1,331 & 2,773 & 1,649 & 2,038 & 2,033 & 2,914 & 2,183 & 4,490 & 1,633 & 1,313 & 1,378 & 830 \\
\hline 2007 Q4 & 32,952 & 1,557 & 2,854 & 1,725 & 2,058 & 2,314 & 3,196 & 2,152 & 4,891 & 1,725 & 1,331 & 1,527 & 855 \\
\hline Total 2007 & 126,628 & 5,479 & 11,373 & 6,836 & 8,428 & 8,938 & 12,272 & 8,645 & 18,587 & 6,664 & 5,498 & 6,110 & 3,382 \\
\hline $2008 Q^{2}{ }^{2}$ & 34,996 & 1,634 & 3,181 & 1,745 & 2,204 & 2,406 & 3,313 & 2,303 & 4,930 & 1,815 & 1,503 & 1,493 & 880 \\
\hline $2008 Q_{2}^{2}$ & 37,174 & 1,629 & 3,315 & 1,884 & 2,123 & 2,509 & 3,585 & 2,424 & 5,336 & 1,931 & 1,656 & 1,493 & 970 \\
\hline $2008 Q^{2}$ & 35,612 & 1,617 & 3,173 & 1,911 & 2,011 & 2,136 & 3,214 & 2,847 & 5,085 & 1,699 & 1,680 & 1,537 & 874 \\
\hline $2008 Q^{2}$ & 32,595 & 1,442 & 2,837 & 1,821 & 1,900 & 1,994 & 2,903 & 2,369 & 5,120 & 1,557 & 1,341 & 1,521 & 835 \\
\hline Total 2008 & 140,377 & 6,323 & 12,506 & 7,362 & 8,238 & 9,045 & 13,015 & 9,944 & 20,471 & 7,002 & 6,179 & 6,044 & 3,559 \\
\hline $2009 Q_{1}^{2}$ & 30,495 & 1,330 & 3,057 & 1,588 & 1,812 & 1,787 & 2,777 & 2,353 & 4,813 & 1,624 & 1,192 & 1,322 & 780 \\
\hline \multicolumn{14}{|c|}{ Non-EU exports } \\
\hline 2007 Q1 & 21,184 & 807 & 2,261 & 1,247 & 1,622 & 1,479 & 1,775 & 3,478 & 3,112 & 917 & 839 & 1,683 & 469 \\
\hline 2007 Q2 & 23,968 & 1,009 & 2,484 & 1,564 & 1,655 & 1,607 & 2,004 & 3,448 & 4,003 & 992 & 957 & 1,991 & 521 \\
\hline 2007 Q3 & 23,008 & 1,021 & 2,417 & 1,402 & 1,685 & 1,595 & 1,843 & 3,402 & 3,667 & 1,100 & 851 & 2,012 & 520 \\
\hline 2007 Q4 & 25,138 & 1,261 & 2,462 & 1,762 & 1,784 & 1,801 & 2,001 & 3,595 & 4,125 & 1,155 & 912 & 1,894 & 578 \\
\hline Total 2007 & 93,297 & 4,098 & 9,624 & 5,975 & 6,746 & 6,482 & 7,623 & 13,922 & 14,906 & 4,164 & 3,559 & 7,580 & 2,088 \\
\hline $2008 Q^{12}$ & 23,867 & 1,164 & 2,452 & 1,641 & 1,743 & 1,767 & 2,167 & 3,195 & 3,892 & 1,053 & 869 & 1,833 & 555 \\
\hline $2008 Q_{2}^{2}$ & 27,803 & 1,335 & 2,862 & 1,712 & 1,941 & 1,989 & 2,509 & 3,661 & 4,993 & 1,178 & 1,074 & 2,066 & 639 \\
\hline $2008 Q^{2}$ & 28,265 & 1,357 & 2,936 & 1,707 & 1,914 & 2,142 & 2,267 & 3,577 & 5,173 & 1,373 & 1,312 & 2,103 & 623 \\
\hline $2008 Q 4^{2}$ & 28,176 & 1,112 & 2,806 & 1,522 & 2,089 & 1,900 & 2,252 & 3,749 & 5,434 & 1,306 & 1,298 & 2,224 & 806 \\
\hline Total 2008 & 108,111 & 4,969 & 11,056 & 6,582 & 7,686 & 7,798 & 9,195 & 14,181 & 19,492 & 4,910 & 4,553 & 8,226 & 2,622 \\
\hline $2009 Q^{12}$ & 22,045 & 963 & 2,665 & 1,219 & 1,891 & 1,161 & 1,834 & 2,540 & 3,942 & 1,087 & 1,049 & 1,917 & 475 \\
\hline \multicolumn{14}{|c|}{ Total Exports } \\
\hline 2007 Q1 & 52,932 & 2,110 & 5,055 & 3,012 & 3,917 & 3,746 & 4,939 & 5,722 & 7,710 & 2,642 & 2,279 & 3,252 & 1,316 \\
\hline 2007 Q2 & 55,233 & 2,297 & 5,436 & 3,260 & 3,691 & 3,932 & 5,003 & 5,514 & 8,612 & 2,572 & 2,371 & 3,627 & 1,371 \\
\hline 2007 Q3 & 53,671 & 2,351 & 5,190 & 3,051 & 3,723 & 3,628 & 4,757 & 5,585 & 8,157 & 2,734 & 2,164 & 3,391 & 1,350 \\
\hline 2007 Q4 & 58,090 & 2,819 & 5,316 & 3,488 & 3,842 & 4,114 & 5,197 & 5,747 & 9,015 & 2,879 & 2,242 & 3,421 & 1,433 \\
\hline 2007 & 219,926 & 9,577 & 20,997 & 12,811 & 15,174 & 15,421 & 19,895 & 22,567 & 33,494 & 10,827 & 9,056 & 13,691 & 5,470 \\
\hline $2008 Q^{2}{ }^{2}$ & 58,863 & 2,798 & 5,633 & 3,386 & 3,947 & 4,173 & 5,480 & 5,498 & 8,823 & 2,868 & 2,372 & 3,326 & 1,435 \\
\hline $2008 Q_{2}^{2}$ & 64,977 & 2,964 & 6,177 & 3,596 & 4,063 & 4,498 & 6,094 & 6,085 & 10,329 & 3,108 & 2,730 & 3,559 & 1,609 \\
\hline $2008 Q^{2}$ & 63,878 & 2,974 & 6,109 & 3,619 & 3,925 & 4,278 & 5,481 & 6,424 & 10,257 & 3,073 & 2,992 & 3,640 & 1,497 \\
\hline $2008 \mathrm{Q} 4^{2}$ & 60,771 & 2,555 & 5,644 & 3,343 & 3,989 & 3,894 & 5,155 & 6,118 & 10,554 & 2,863 & 2,639 & 3,744 & 1,641 \\
\hline $2008^{2}$ & 248,489 & 11,291 & 23,562 & 13,944 & 15,924 & 16,843 & 22,210 & 24,124 & 39,963 & 11,911 & 10,732 & 14,270 & 6,182 \\
\hline $2009 \mathrm{Q}^{2}$ & 52,540 & 2,293 & 5,722 & 2,807 & 3,702 & 2,947 & 4,611 & 4,894 & 8,754 & 2,710 & 2,241 & 3,239 & 1,255 \\
\hline
\end{tabular}

Notes: $\quad$ Source: UK Regional Trade in Goods Statistics, HM Revenue \& Customs

1 Components may not sum to totals as a result of rounding

2 Provisional

qualifications in each region, alongside the UK average, for 2008 Q4. Northern Ireland had the highest proportion of the population with no qualifications (10.4 percentage points above the UK average), whereas the South East and the South West had the lowest proportions, 3.4 and 3.2 percentage points below the UK average, respectively.

Above average proportions of workingage people without a qualification do not necessarily mean that regions have the most unqualified workforce. Due to differing regional skill requirements, people with recognised qualifications might migrate into other regions, where demand for their qualifications is high, while those without any recognised qualifications might migrate out of these other regions. Also, if employers have a strong demand for lower skills and a good supply of appropriate workers, a low skill equilibrium is created in a region.

Regional Skills Partnerships (RSPs) are groups brought together by Regional Development Agencies in each region of England in response to the National Skills Strategy. RSPs aim to strengthen regional structures to make skills provision more relevant to the needs of employers and individuals, covering private, public and voluntary sectors of the economy. They also aim to give regions the flexibility to tackle their own individual challenges and priorities.

Table 4 presents the RSP core indicators, which help to monitor the health of regional and local labour markets and progress towards national skills targets such as those documented in the Leitch Report. These core indicators will be supported by local, more specific, indicators identified by individual RSPs. The choice of ' 19 to state pension age' for some of the indicators in Table 5 has been influenced by: the 


\section{Figure 16 \\ Working-age population with no qualifications: ${ }^{1}$ by NUTS1 region, 2008 Q4}

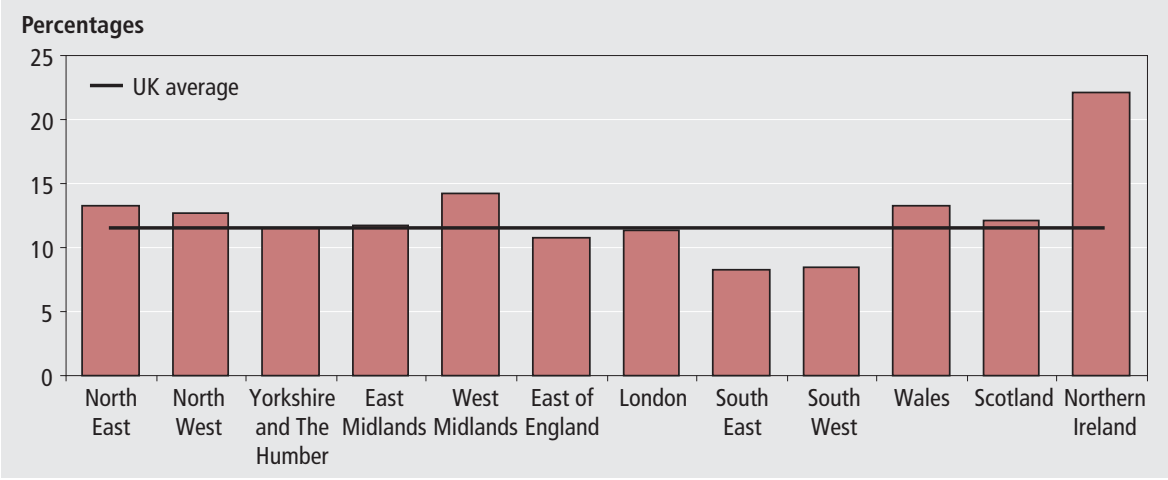

Note:

Source: Labour Force Survey, Office for National Statistics

1 For summary of qualifications and equivalents see

www.statistics.gov.uk/statbase/Product.asp?vlnk=836

Figure 17

Pupils achieving five or more grades $\mathrm{A}^{*}$ to $\mathrm{C}$ at GCSE level or equivalent in (i) all subjects and (ii) subjects including English and Mathematics: by NUTS1 region, 2007/08

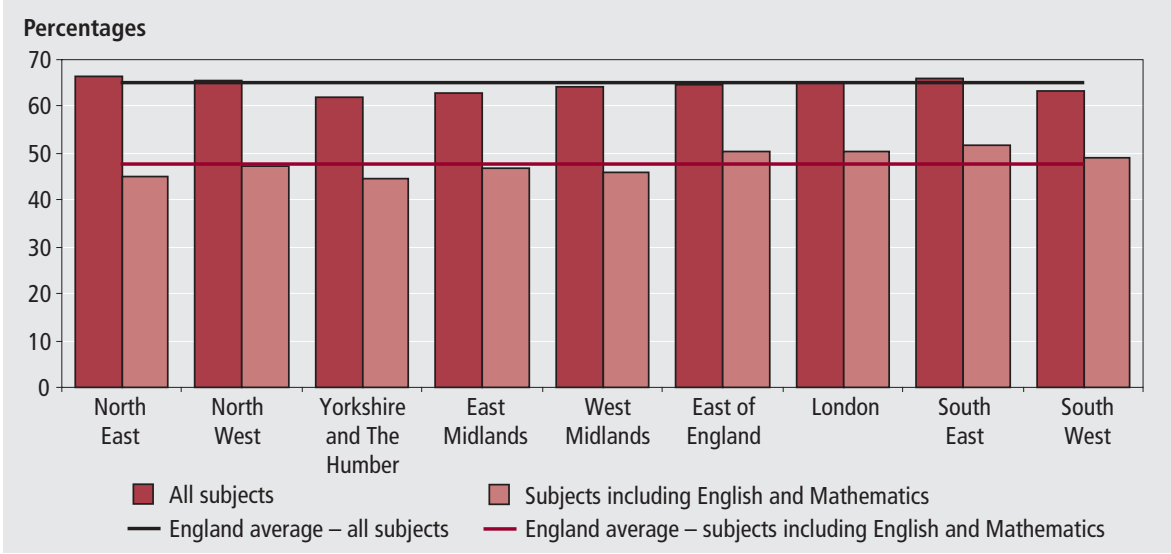

\section{Note:}

Source: Department for Children, Schools and Families

1 Revised data, includes attempts and achievements by these pupils in previous academic years.

2 The England average includes all schools, not only local authority maintained schools.

increased emphasis on education and training after the age of 16 ; the plan to raise the standard school leaving age to 18 ; and alignment with indicators specified in the Local Area Agreements.

In order to assess the future capabilities of the labour force, the percentage of pupils achieving five or more grades $\mathrm{A}^{*}$ to $\mathrm{C}$ at GCSE level or equivalent in each English region can be used as an indicator ${ }^{3}$. Recent focus on literacy and numeracy has led to a new measure being published, of five or more GCSEs grade $A^{\star}$ to $C$ in subjects including English and Mathematics.

Figure 17 shows the percentage of pupils achieving at least five grades $A^{\star}$ to $C$ at GCSE level or equivalent in any subjects, and in subjects including English and Mathematics.

In 2007/2008, the England average for pupils in all schools achieving five or more grades $A^{*}$ to $C$ in any subjects was 65 per cent, while it was down to 48 per cent if the subjects included English and Mathematics. Across all English regions, the percentage of pupils achieving at least five grades $A^{\star}$ to $C$ in subjects including English and Mathematics was substantially lower compared with achieving the same in any subjects. Also, regional differences were more pronounced when subjects included English and Mathematics. In the North East the percentage of pupils achieving five or more grades $A^{\star}$ to $C$ in any subjects was slightly above the England average, but the percentage dropped 2.7 points below the average when the subjects included English and Mathematics. The opposite held for the South West, London and the East of England, where the proportion of pupils achieving at least five grades $A^{*}$ to $C$ increased above the England average if the subjects included English and Mathematics while it dropped slightly below national average for achieving five or more grades $\mathrm{A}^{*}$ to $\mathrm{C}$ in any subject. South East was the only region which performed above national average on both measures.

\section{The labour market}

Table 5 shows the seasonally adjusted employment rate, the number of people of working age in employment, expressed as a proportion of the population, from the Labour Force Survey (LFS).

In quarter one (January to March) of 2009, the UK employment rate was 73.6 per cent, down 1.3 percentage points from a year ago and down 0.5 percentage points from quarter four (October to December) of 2008. Regional rates varied from 78.2 per cent in the South East to 66.9 per cent in Northern Ireland.

Eleven of the twelve UK regions experienced annual falls in the employment rate. The West Midlands had an annual fall of 2.9 percentage points while Northern Ireland had an annual fall of 2.8 percentage points. The employment rate in the remaining region, the East of England, was unchanged.

Table 6 shows the unemployment rate (according to the internationally-consistent International Labour Organisation definition) for persons aged 16 and over from the LFS. The UK rate in the first quarter of 2009 was 7.1 per cent, up 1.9 percentage points from a year ago and up 0.8 percentage points on the last quarter. Regionally, the rates ranged from 9.3 per cent in the West Midlands to 5.3 per cent in the South East.

Over the year the unemployment rate rose in all regions. The West Midlands had the largest increase (up by 3.1 percentage points), followed by Yorkshire and The Humber (up by 3.0 percentage points). The smallest increase was in Scotland and London both at 1.3 percentage points.

Table 7 shows economic inactivity rates for persons of working age from the LFS. The UK rate in the first quarter of 2009 was 20.7 per cent, down 0.1 percentage points from the previous quarter and down 0.2 percentage points on a year earlier. Across the regions, rates varied from 17.2 per cent in both the South East and South West to 28.6 per cent in Northern Ireland.

Compared with a year earlier, eight regions had a decrease in the inactivity rate, and thus a corresponding increase in the working-age activity rate. The East had the largest annual fall of 1.2 percentage 
Table 4

Regional Skills Partnerships core indicators: by NUTS1 region

Percentages

\begin{tabular}{|c|c|c|c|c|c|c|c|c|c|c|c|}
\hline & & & & Yorkshire & & & & & & & \\
\hline & $\begin{array}{r}\text { Time } \\
\text { period }\end{array}$ & $\begin{array}{r}\text { North } \\
\text { East }\end{array}$ & $\begin{array}{r}\text { North } \\
\text { West }\end{array}$ & $\begin{array}{l}\text { and The } \\
\text { Humber }\end{array}$ & $\begin{array}{r}\text { East } \\
\text { Midlands }\end{array}$ & $\begin{array}{r}\text { West } \\
\text { Midlands }\end{array}$ & $\begin{array}{l}\text { East of } \\
\text { England }\end{array}$ & London & $\begin{array}{r}\text { South } \\
\text { East }\end{array}$ & $\begin{array}{r}\text { South } \\
\text { West }\end{array}$ & England \\
\hline Skills outcome indicators & & & & & & & & & & & \\
\hline $\begin{array}{l}\text { Percentage of employers with business or } \\
\text { training plan, or budget for training }\end{array}$ & 2007 & 70.6 & 69.2 & 69.6 & 67.9 & 67.5 & 67.3 & 70.0 & 70.6 & 68.4 & 69.1 \\
\hline Percentage of staff with skill gaps & 2007 & 6.3 & 5.3 & 4.8 & 6.8 & 5.4 & 7.8 & 6.7 & 5.8 & 6.2 & 6.1 \\
\hline $\begin{array}{l}\text { Skill shortage vacancies (SSVI) as } \\
\text { percentage of all vacancies }\end{array}$ & 2007 & 18.8 & 17.6 & 20.1 & 20.2 & 15.5 & 19.6 & 26.1 & 22.5 & 20.9 & 20.9 \\
\hline $\begin{array}{l}\text { Percentage of KS4 pupils achieving } 5+A^{*} \text { to } \\
\text { C GCSE (inc Maths and English) }\end{array}$ & $2007 / 08$ & 44.9 & 47.4 & 44.4 & 47.0 & 46.1 & 50.3 & 50.6 & 51.7 & 49.2 & 47.6 \\
\hline $\begin{array}{l}\text { Percentage of } 19 \text { year olds qualified to Level } \\
2 \text { or above } 1\end{array}$ & 2008 & 75.9 & 74.3 & 73.2 & 73.1 & 74.9 & 77.0 & 77.0 & 79.6 & 77.0 & 76.7 \\
\hline $\begin{array}{l}\text { Percentage of } 19 \text { year olds qualified to Level } \\
3 \text { or above1 }\end{array}$ & 2008 & 43.7 & 46.1 & 44.4 & 46.0 & 46.9 & 52.4 & 51.9 & 56.9 & 51.0 & 49.8 \\
\hline $\begin{array}{l}\text { Percentage of } 19 \text { to state pension age with } \\
\text { Level } 2+\end{array}$ & 2008 & 69.3 & 68.1 & 67.6 & 67.0 & 65.8 & 67.6 & 71.0 & 73.1 & 72.2 & 69.4 \\
\hline $\begin{array}{l}\text { Percentage of } 19 \text { to state pension age with } \\
\text { Level } 3+\end{array}$ & 2008 & 46.9 & 47.1 & 47.1 & 46.3 & 45.2 & 46.5 & 55.0 & 53.7 & 51.7 & 49.5 \\
\hline $\begin{array}{l}\text { Percentage of } 19 \text { to state pension age with } \\
\text { Level } 4+\end{array}$ & 2008 & 25.4 & 27.4 & 26.6 & 27.0 & 26.2 & 27.8 & 40.6 & 33.6 & 30.2 & 25.4 \\
\hline $\begin{array}{l}\text { Percentage of } 19 \text { to state pension age with } \\
\text { no qualifications }\end{array}$ & 2008 & 13.2 & 14.4 & 12.9 & 12.8 & 15.6 & 11.5 & 11.6 & 8.5 & 8.4 & 11.9 \\
\hline $\begin{array}{l}\text { Percentage of working-age population who } \\
\text { undertook job-related training in last } 13 \\
\text { weeks }\end{array}$ & 2008 & 20.9 & 18.9 & 19.4 & 20.2 & 19.4 & 18.7 & 18.2 & 22.2 & 23.1 & 20.0 \\
\hline $\begin{array}{l}\text { Percentage of } 17 \text { year olds in education or } \\
\text { work-based learning }\end{array}$ & end-2007 & 78.0 & 77.0 & 74.0 & 74.0 & 78.0 & 77.0 & 86.0 & 77.0 & 77.0 & 78.0 \\
\hline
\end{tabular}

\section{Note:}

1 Provisional data from DCSF matched datasets.

Source: Office for National Statistics; Labour Force Survey; Department of Business Enterprise and Regulatory Reform; Department for Children, Schools and Families; Department for Innovation Universities and Skills; National Employers Skills Survey 2007.

Table 5

Employment ${ }^{1}$ rates for people of working age: by NUTS1 region

Percentages, seasonally adjusted

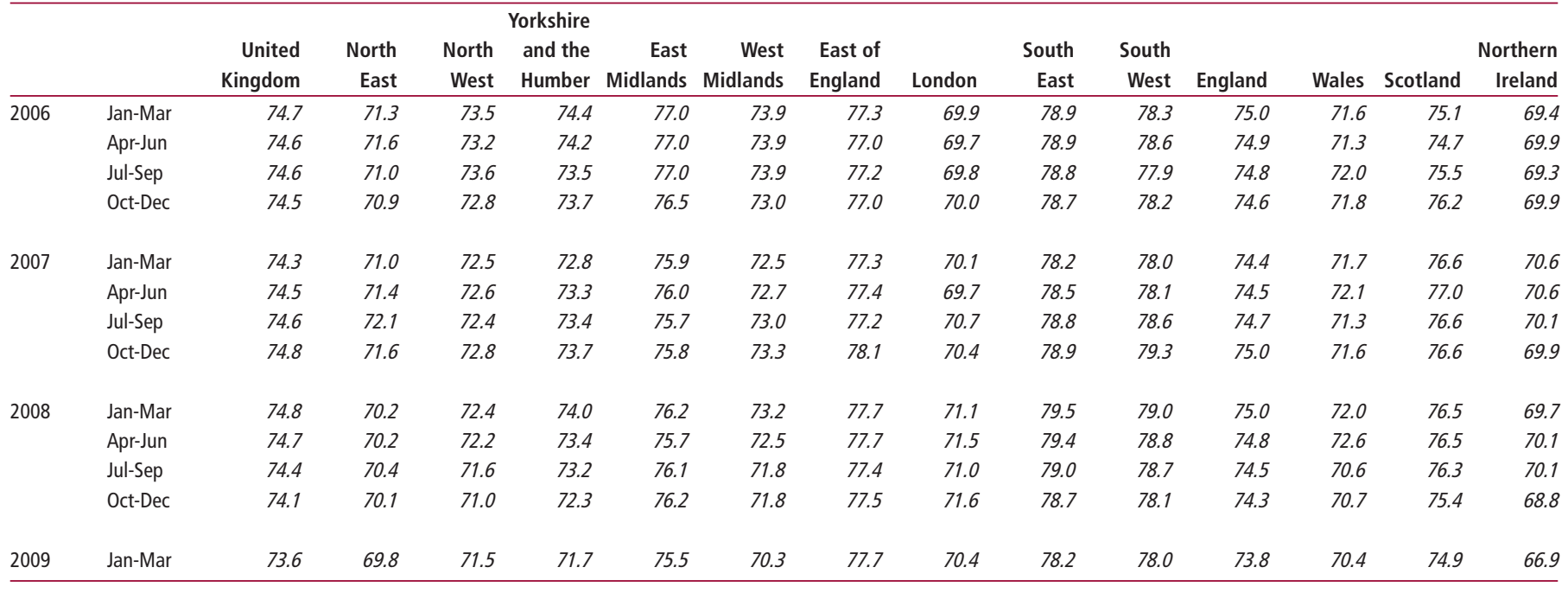

Note:

Source: Labour Force Survey, Office for National Statistics

1 Includes employees, self-employed, participants on government-supported training schemes and unpaid family workers.

points. Four regions had an increase in the economic inactivity rate over the year. The largest annual rise was in Northern Ireland with 1.7 percentage points.

Table 8 shows the number of employee jobs, not seasonally adjusted, from the Employers Surveys. The number of UK employee jobs was $26,568,000$, a decrease of 550,000 over the year since March 2008.
In percentage terms, this was a 2.0 per cent decrease.

There were annual decreases in all twelve regions. The largest percentage decrease was in the West Midlands (-3.5 per cent).

Table 9 shows the claimant count rate (referring to people claiming Jobseeker's Allowance benefits as a proportion of the workforce). The UK rate was 4.8 per cent in June 2009, up 0.1 percentage points from May 2009, and up 2.2 percentage points on a year earlier. This national rate masks large variations between regions and component countries of the UK. For June 2009, the North East had the highest claimant count rate in the UK at 7.1 per cent. The North East was followed by the West Midlands (6.4 per cent), and 
Table 6

Unemployment rates for people aged 16 and over: by NUTS1 region

Percentages, seasonally adjusted

\begin{tabular}{|c|c|c|c|c|c|c|c|c|c|c|c|c|c|c|c|}
\hline & & $\begin{array}{r}\text { United } \\
\text { Kingdom }\end{array}$ & $\begin{array}{r}\text { North } \\
\text { East }\end{array}$ & $\begin{array}{r}\text { North } \\
\text { West }\end{array}$ & $\begin{array}{c}\text { Yorkshire } \\
\text { and the } \\
\text { Humber }\end{array}$ & $\begin{array}{r}\text { East } \\
\text { Midlands }\end{array}$ & $\begin{array}{r}\text { West } \\
\text { Midlands }\end{array}$ & $\begin{array}{l}\text { East of } \\
\text { England }\end{array}$ & London & $\begin{array}{r}\text { South } \\
\text { East }\end{array}$ & $\begin{array}{r}\text { South } \\
\text { West }\end{array}$ & England & Wales & Scotland & $\begin{array}{r}\text { Northern } \\
\text { Ireland }\end{array}$ \\
\hline \multirow[t]{4}{*}{2006} & Jan-Mar & 5.2 & 6.5 & 4.9 & 5.4 & 5.0 & 5.3 & 4.9 & 7.6 & 4.5 & 3.6 & 5.3 & 4.8 & 5.3 & 4.3 \\
\hline & Apr-Jun & 5.5 & 6.1 & 5.3 & 5.8 & 5.5 & 5.6 & 5.0 & 7.8 & 4.7 & 3.8 & 5.5 & 5.6 & 5.5 & 4.3 \\
\hline & Jul-Sep & 5.5 & 6.7 & 5.5 & 6.0 & 5.3 & 6.1 & 4.8 & 7.8 & 4.5 & 3.8 & 5.6 & 5.4 & 5.0 & 4.7 \\
\hline & Oct-Dec & 5.5 & 6.7 & 5.4 & 6.0 & 5.7 & 6.7 & 4.5 & 7.7 & 4.3 & 3.9 & 5.6 & 5.3 & 5.2 & 4.2 \\
\hline \multirow[t]{4}{*}{2007} & Jan-Mar & 5.5 & 6.8 & 5.8 & 6.3 & 5.5 & 6.5 & 4.8 & 7.1 & 4.7 & 4.0 & 5.6 & 5.6 & 4.9 & 4.1 \\
\hline & Apr-Jun & 5.4 & 6.3 & 5.8 & 5.5 & 5.0 & 6.7 & 4.6 & 7.4 & 4.3 & 4.0 & 5.5 & 5.5 & 4.7 & 3.8 \\
\hline & Jul-Sep & 5.3 & 6.1 & 6.0 & 5.4 & 5.7 & 6.4 & 5.1 & 6.1 & 4.5 & 4.0 & 5.4 & 5.3 & 4.8 & 3.8 \\
\hline & Oct-Dec & 5.2 & 5.8 & 5.9 & 5.3 & 5.2 & 5.8 & 4.4 & 6.6 & 4.5 & 3.7 & 5.2 & 5.1 & 4.9 & 4.2 \\
\hline \multirow[t]{4}{*}{2008} & Jan-Mar & 5.2 & 6.5 & 6.0 & 5.0 & 5.5 & 6.2 & 4.5 & 6.9 & 3.9 & 3.7 & 5.3 & 5.4 & 4.6 & 4.6 \\
\hline & Apr-Jun & 5.4 & 7.5 & 6.3 & 6.1 & 5.7 & 6.3 & 4.6 & 6.9 & 4.2 & 3.8 & 5.6 & 4.9 & 4.2 & 4.2 \\
\hline & Jul-Sep & 5.8 & 8.0 & 6.8 & 6.8 & 5.9 & 6.5 & 4.8 & 7.4 & 4.6 & 4.2 & 6.0 & 6.7 & 4.7 & 4.1 \\
\hline & Oct-Dec & 6.3 & 8.4 & 7.8 & 6.6 & 6.1 & 7.7 & 5.5 & 7.2 & 4.9 & 4.7 & 6.4 & 7.0 & 5.1 & 5.1 \\
\hline 2009 & Jan-Mar & 7.1 & 8.3 & 7.9 & 8.0 & 7.1 & 9.3 & 5.9 & 8.2 & 5.3 & 5.7 & 7.2 & 7.7 & 5.9 & 6.1 \\
\hline
\end{tabular}

Source: Labour Force Survey, Office for National Statistics

Table 7

Economic inactivity rates for people of working age: by NUTS1 region

Percentages, seasonally adjusted

\begin{tabular}{|c|c|c|c|c|c|c|c|c|c|c|c|c|c|c|c|}
\hline & & $\begin{array}{r}\text { United } \\
\text { Kingdom }\end{array}$ & $\begin{array}{r}\text { North } \\
\text { East }\end{array}$ & $\begin{array}{l}\text { North } \\
\text { West }\end{array}$ & $\begin{array}{l}\text { Yorkshire } \\
\text { and the } \\
\text { Humber }\end{array}$ & $\begin{array}{r}\text { East } \\
\text { Midlands }\end{array}$ & $\begin{array}{r}\text { West } \\
\text { Midlands }\end{array}$ & $\begin{array}{l}\text { East of } \\
\text { England }\end{array}$ & London & $\begin{array}{r}\text { South } \\
\text { East }\end{array}$ & $\begin{array}{r}\text { South } \\
\text { West }\end{array}$ & England & Wales & Scotland & $\begin{array}{r}\text { Northern } \\
\text { Ireland }\end{array}$ \\
\hline \multirow[t]{4}{*}{2006} & Jan-Mar & 21.1 & 23.7 & 22.7 & 21.3 & 18.8 & 21.9 & 18.6 & 24.2 & 17.4 & 18.7 & 20.7 & 24.7 & 20.6 & 27.5 \\
\hline & Apr-Jun & 21.0 & 23.6 & 22.6 & 21.2 & 18.4 & 21.5 & 18.8 & 24.3 & 17.1 & 18.3 & 20.6 & 24.3 & 20.9 & 26.9 \\
\hline & Jul-Sep & 21.0 & 23.9 & 22.0 & 21.7 & 18.6 & 21.2 & 18.8 & 24.1 & 17.5 & 18.9 & 20.7 & 23.8 & 20.5 & 27.2 \\
\hline & Oct-Dec & 21.1 & 23.9 & 22.9 & 21.5 & 18.7 & 21.6 & 19.1 & 24.0 & 17.7 & 18.5 & 20.8 & 24.0 & 19.6 & 27.0 \\
\hline \multirow[t]{4}{*}{2007} & Jan-Mar & 21.2 & 23.7 & 22.9 & 22.2 & 19.6 & 22.3 & 18.6 & 24.4 & 17.9 & 18.6 & 21.1 & 23.9 & 19.4 & 26.3 \\
\hline & Apr-Jun & 21.2 & 23.8 & 22.7 & 22.3 & 20.0 & 21.8 & 18.8 & 24.6 & 17.8 & 18.5 & 21.1 & 23.5 & 19.1 & 26.6 \\
\hline & Jul-Sep & 21.1 & 23.1 & 22.9 & 22.4 & 19.6 & 21.8 & 18.5 & 24.6 & 17.4 & 18.0 & 20.9 & 24.5 & 19.4 & 27.0 \\
\hline & Oct-Dec & 21.0 & 23.9 & 22.5 & 22.0 & 19.9 & 22.1 & 18.2 & 24.4 & 17.2 & 17.6 & 20.8 & 24.5 & 19.4 & 27.0 \\
\hline \multirow[t]{4}{*}{2008} & Jan-Mar & 20.9 & 24.8 & 22.8 & 22.0 & 19.2 & 21.7 & 18.5 & 23.5 & 17.1 & 17.9 & 20.7 & 23.8 & 19.6 & 26.9 \\
\hline & Apr-Jun & 20.9 & 24.0 & 22.7 & 21.7 & 19.5 & 22.4 & 18.5 & 23.1 & 17.1 & 18.0 & 20.6 & 23.5 & 20.0 & 26.8 \\
\hline & Jul-Sep & 20.9 & 23.3 & 23.0 & 21.2 & 19.0 & 23.0 & 18.6 & 23.2 & 17.2 & 17.7 & 20.6 & 24.2 & 19.8 & 26.9 \\
\hline & Oct-Dec & 20.8 & 23.3 & 22.8 & 22.5 & 18.7 & 22.1 & 17.8 & 22.7 & 17.1 & 17.9 & 20.4 & 23.8 & 20.3 & 27.4 \\
\hline 2009 & Jan-Mar & 20.7 & 23.7 & 22.2 & 21.9 & 18.5 & 22.3 & 17.3 & 23.2 & 17.2 & 17.2 & 20.3 & 23.5 & 20.2 & 28.6 \\
\hline
\end{tabular}

Source: Labour Force Survey, Office for National Statistics

Table 8

Employee jobs: ${ }^{1}$ by NUTS1 region

Thousands, not seasonally adjusted

\begin{tabular}{|c|c|c|c|c|c|c|c|c|c|c|c|c|c|c|}
\hline & $\begin{array}{r}\text { United } \\
\text { Kingdom }\end{array}$ & $\begin{array}{r}\text { North } \\
\text { East }\end{array}$ & $\begin{array}{l}\text { North } \\
\text { West }\end{array}$ & $\begin{array}{c}\text { Yorkshire } \\
\text { and the } \\
\text { Humber }\end{array}$ & $\begin{array}{r}\text { East } \\
\text { Midlands }\end{array}$ & $\begin{array}{r}\text { West } \\
\text { Midlands }\end{array}$ & $\begin{array}{l}\text { East of } \\
\text { England }\end{array}$ & London & $\begin{array}{r}\text { South } \\
\text { East }\end{array}$ & $\begin{array}{r}\text { South } \\
\text { West }\end{array}$ & England & Wales & Scotland & $\begin{array}{r}\text { Northern } \\
\text { Ireland } \\
\end{array}$ \\
\hline Mar 05 & 26,642 & 1,028 & 3,005 & 2,220 & 1,815 & 2,325 & 2,299 & 3,963 & 3,641 & 2,158 & 22,455 & 1,149 & 2,342 & 696 \\
\hline Mar 06 & 26,792 & 1,039 & 2,953 & 2,211 & 1,832 & 2,328 & 2,319 & 3,984 & 3,680 & 2,207 & 22,554 & 1,164 & 2,368 & 706 \\
\hline Mar 07 & 26,879 & 1,036 & 3,001 & 2,219 & 1,865 & 2,322 & 2,341 & 4,013 & 3,646 & 2,174 & 22,617 & 1,176 & 2,371 & 715 \\
\hline Mar 08 & 27,118 & 1,031 & 2,994 & 2,216 & 1,891 & 2,339 & 2,366 & 4,081 & 3,720 & 2,208 & 22,848 & 1,154 & 2,382 & 734 \\
\hline Jun 08 & 27,221 & 1,029 & 2,999 & 2,220 & 1,894 & 2,346 & 2,381 & 4,095 & 3,743 & 2,227 & 22,935 & 1,156 & 2,396 & 734 \\
\hline Sep 08 & 27,140 & 1,030 & 2,996 & 2,208 & 1,883 & 2,326 & 2,387 & 4,074 & 3,732 & 2,237 & 22,873 & 1,152 & 2,387 & 728 \\
\hline Dec 08 & 27,018 & 1,036 & 2,987 & 2,187 & 1,876 & 2,319 & 2,378 & 4,063 & 3,712 & 2,209 & 22,767 & 1,145 & 2,385 & 721 \\
\hline Mar 09 & 26,568 & 1,018 & 2,948 & 2,153 & 1,829 & 2,258 & 2,332 & 4,011 & 3,647 & 2,188 & 22,385 & 1,116 & 2,352 & 715 \\
\hline
\end{tabular}

Note:

Source: Employer Surveys

1 Employee jobs figures are a measure of jobs rather than people. For example, if a person holds two jobs, each job will be counted in the employee jobs total. Employee jobs figures come from quarterly surveys of employers carried out by ONS and administrative sources. 
Table 9

\section{Claimant count rates:' by NUTS1 region}

Percentages, seasonally adjusted

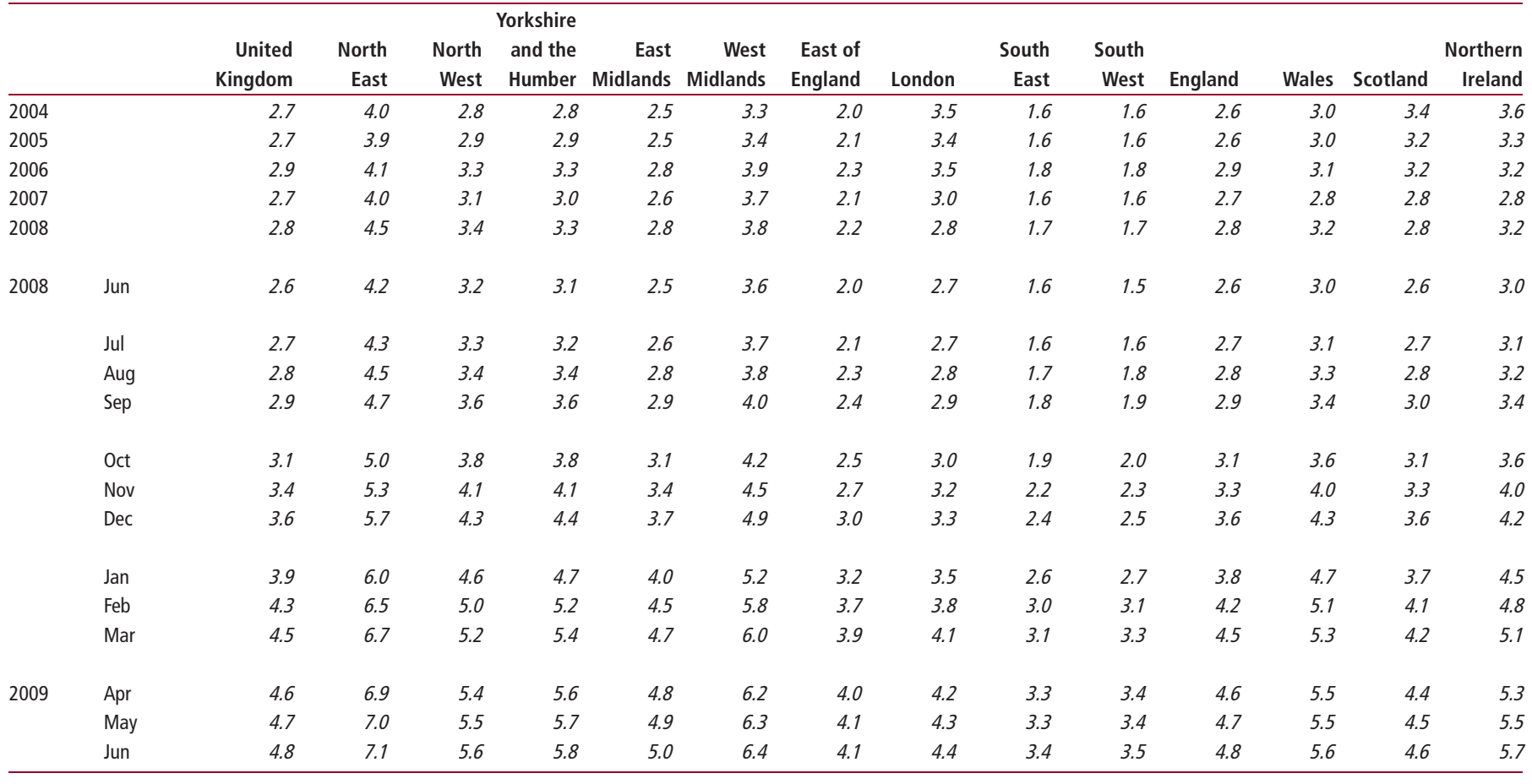

Note:

Source: Jobcentre Plus administrative system

1 Count of claimants of Jobseeker's Allowance expressed as a percentage of the total workforce - that is, workforce jobs plus claimants.

Yorkshire and The Humber (5.8 per cent). The lowest claimant count was measured in the South East (3.4 per cent). The claimant count rate was 4.6 per cent in Scotland, 5.7 per cent in Northern Ireland and 5.6 per cent in Wales.

All regions had an increase in the claimant count rate compared with a year ago. The largest increases were in the North East (2.9 percentage points) and the West Midlands (2.8 percentage points).

\section{Notes}

1 Certain urban areas with between 10,000 and 30,000 population are identified as 'larger market towns' and are taken into account in assessing the rurality of a district. Such towns are identified by the presence of a prescribed set of services and commercial attributes. Here, the populations of 207 'larger market towns' contribute to the rural population of the districts in which they are located, although within the Rural/Urban definition they are identified as urban and their populations are not included in the rural domain.

2 UK Regional Trade in Goods Statistics, Quarter 1 2009, HM Revenue and Customs at www.uktradeinfo.com/index. cfm?task=td_regstats_press
3 For a summary of all different levels of qualifications, see 'Notes and definitions' at www.statistics.gov.uk/statbase/product. asp?vlnk $=836$

\section{CONTACT}

凶elmr@ons.gsi.gov.uk

\section{REFERENCES}

Department for Children, Schools and

Families (2008) GCSE and Equivalent

Examination Results in England 2007/08

(Revised) Statistical First Release at

www.dcsf.gov.uk/rsgateway/DB/SFR/

s000826/index.shtml

Department for Innovation, Universities and Skills (2006) Leitch Review of Skills at www.dcsf.gov.uk/furthereducation/index. $\mathrm{cfm}$ ?fuseaction $=$ content.view $\&$ Categoryl $\mathrm{D}=$ 21\&ContentID $=37$

Department for Innovation, Universities and Skills (2008) The Level of Highest Qualification Held by Adults: England 2007(Revised) Statistical First Release at www.dcsf.gov.uk/rsgateway/DB/SFR/ s000798/index.shtml

Dey-Chowdhury S and Gibson P (2008)

'Experimental estimates of rural-urban productivity ', Economic \& Labour Market
Review 2(11), pp 40-43 and at www.statistics.gov.uk/cci/article. asp? $\mathrm{id}=2068$

Dey-Chowdhury S, Penny D, Walker M and Wosnitza B (2008) 'Regional Economic Indicators February 2008 with a focus on regional productivity' Economic \& Labour Market Review 3(1), pp 18-30 and at www.statistics.gov.uk/cci/article. asp? id $=2103$

Dunnell K (2009) 'National Statistician's article: measuring regional economic performance' Economic \& Labour Market Review 3(1), pp 18-30 and at www. statistics.gov.uk/cci/article. $a s p ? i d=2103$ Grierson and Allen (2008) 'Introducing the new business demography statistics' Economic \& Labour Market Review 2(12), pp 53-5 and at

www.statistics.gov.uk/cci/article. asp?id $=2096$

HM Revenue \& Customs (2009) UK Regional Trade Statistics Quarter 12009 at www.uktradeinfo.com/index.cfm?task=td_ regstats_press

HM Treasury (2004) Productivity in the UK 5: Benchmarking UK Productivity Performance. A Consultation on Productivity Indicators at www.hm-treasury.gov.uk/consult_ productivity_indicators_index.htm 
Office for National Statistics Annual Survey of Hours and Earnings at

www.statistics.gov.uk/statbase/product.

asp?vlnk=13101

Office for National Statistics Business

Demography at

www.statistics.gov.uk/statbase/product.

asp?vlnk=15186

Office for National Statistics Business Expenditure on Research \& Development by Government Office Region at www.statistics.gov.uk/statbase/tsdataset. asp?vInk=572

Office for National Statistics Regional Household Income May 2008 Statistical First Release at www.statistics.gov.uk/statbase/product. asp?vlnk=14651

Office for National Statistics Regional, subregional and gross value added, December 2008 at

www.statistics.gov.uk/statbase/Product. asp?vlnk=14650
Office for National Statistics Regional Trends 37: Notes and Definitions at www.statistics.gov.uk/statbase/product. asp? vlnk $=836$

Office for National Statistics (2007) The ONS

Productivity Handbook: A Statistical Overview and Guide at

www.ons.gov.uk/about-statistics/userguidance/productivity-handbook/index.html

Organisation for Economic Co-operation and Development (2002) Frascati Manual: Proposed Standard Practice for Surveys on Research and Experimental Development Organisation for Economic Co-operation and Development (2003) 'Identifying the Determinants of Regional Performances' Working Party on Territorial Indicators

The Countryside Agency, Department for Food, Environment and Rural Affairs, Office of the Deputy Prime Minister, Office for National Statistics, Welsh Assembly Government (2005), Rural and Urban Area
Classification 2004, An Introductory Guide at www.defra.gov.uk/rural/ruralstats/rural-defn/ Rural_Urban_Introductory_Guide.pdf

Turvey A, Knight J and Wosnitza B (2009)

'Regional Economic Indicators May 2009 with a focus on household income' Economic \& Labour Market Review 3(5), pp 55-68 and at www.statistics.gov.uk/elmr/05_09/

Wosnitza B, Tyrrell K and Knight J (2009) 'Regional Economic Indicators February 2009 with a focus on enterprise - driving regional productivity' Economic \& Labour Market Review 3(2), pp 54-67 and at www.statistics.gov.uk/elmr/02_09/ 